\title{
A building classification scheme of housing stock in Malawi for earthquake risk assessment
}

\author{
Panos Kloukinas ${ }^{1}$ (D) Viviana Novelli ${ }^{2} \cdot$ Innocent Kafodya ${ }^{3} \cdot$ Ignasio Ngoma $^{3}$. \\ John Macdonald ${ }^{2} \cdot$ Katsuichiro Goda ${ }^{4}$
}

Received: 13 April 2018 / Accepted: 17 July 2019 / Published online: 2 August 2019

(c) The Author(s) 2019

\begin{abstract}
This study presents a building classification scheme for residential houses in Malawi by focusing upon informal construction, which accounts for more than $90 \%$ of housing in the country with the highest urbanisation rate in the world. The proposed classification is compatible with the Prompt Assessment of Global Earthquakes for Response (PAGER) method and can be used for seismic vulnerability assessments of building stock in Malawi. To obtain realistic proportions of the building classes that are prevalent in Malawi, a building survey was conducted in Central and Southern Malawi between 10th and 20th July 2017. The results from the survey are used to modify the PAGER-based proportions of main housing typologies by reflecting actual housing construction in the surveyed areas. The results clearly highlight the importance of using realistic building stock data for seismic risk assessment in Malawi; relying on global building stock information can result in significant bias of earthquake impact assessment.
\end{abstract}

Keywords Field survey $\cdot$ Building classification · Earthquake, seismic vulnerability $\cdot$ Risk assessment $\cdot$ Sustainable development

\section{Introduction}

Malawi is a landlocked country in Sub-Saharan Africa. The country ranks 171th worldwide according to the 2018 Human Development Index (HDI-UNDP 2018), and faces various economic and social challenges, including population growth, poverty, a volatile economy, and fast-degrading environment. Between 2008 and 2018, its population increased from $13,029,498$ to $17,563,749$ (i.e. $35 \%$ increase over a decade), with a high annual rate of 2.9\% (National Statistical Office of Malawi 2018). Most of the population is rural and is engaged in agriculture, whilst urbanisation is increasing at the highest rate in the world, of about $6 \%$ (UN-Habitat 2010), changing the risk profiles of the country rapidly.

Malawi is prone to multiple natural hazards, including floods, drought, strong winds, hailstorms, landslides and earthquakes. The potential impact of major disasters on local

Panos Kloukinas

p.kloukinas@greenwich.ac.uk

Extended author information available on the last page of the article 
communities in Malawi is high. Over the period between 1979 and 2010, more than 21.7 million people were cumulatively affected by natural disasters, claiming more than 2500 fatalities (Government of Malawi 2015b). In recent years, floods have caused major damage and loss to numerous cities and townships in the Lower Shire Basin. For instance, the 2015 flood event impacted a large area of Southern Malawi, causing economic losses of US\$335 million, which is equivalent to approximately 5.0\% of Gross Domestic Product (Government of Malawi 2015a). Meanwhile, seismic hazard is not negligible because Malawi is located within the western branch of the East African Rift System (Hodge et al. 2015; Poggi et al. 2017), where large earthquakes of moment magnitude $\left(M_{\mathrm{w}}\right) 7+$ have occurred in the past (e.g. 1910 Rukwa Tanzania and 2006 Mozambique earthquakes). In Malawi, two earthquakes have caused major damage in recent decades; the 1989 Salima and the 2009 Karonga earthquakes, which affected tens of thousands of people severely (their properties damaged or lost and them being displaced or made homeless), resulted in economic losses of about US\$28 million and US\$14 million, respectively (Chapola and Gondwe 2016). In the above-mentioned natural disasters, the housing and agriculture sectors were impacted most significantly.

Responding to the recent crises triggered by natural hazard events, the Government of Malawi published the national disaster risk management policy and aimed at promoting more coordinated actions by various governmental departments and non-governmental organisations to achieve disaster risk reduction and effective sustainable development (Government of Malawi 2015b). The Department of Disaster Management Affairs implements various disaster risk management programmes, in close partnership with other governmental agencies (e.g. Department of Lands, Housing and Urban Development and Departments of Building) and various international aid organisations (e.g. Department for International Development-DFID, Global Facility for Disaster Reduction and Recovery-GFDRR, Red Cross, UN-Habitat, United Nations Development Programme-UNDP, and World Bank). These programmes are fully aligned with global initiatives for disaster risk reduction and sustainable development, such as the United Nations International Strategy for Disaster Reduction-UNISDR's Hyogo Framework for Actions 2005-2015 (2007) and the Sendai Framework for disaster risk reduction 2015-2030 (2015).

The built environment in Malawi, particularly housing construction, has a crucial influence in determining the socioeconomic impact of natural disasters and in achieving environmentally sustainable, affordable solutions (Ngoma 2005; UN-Habitat 2010). Houses and people who live there are important and the main backbone of society. Yet, houses in local communities are one of the most vulnerable elements. The main technical/construction-related reasons for high vulnerability of houses against natural hazards are multi-fold: (i) poor quality of construction materials (e.g. use of unburnt bricks with mud mortar), (ii) poor and variable construction practice (e.g. lack of skilled labour), and (iii) lack of building design and construction provisions for natural disasters, such as floods and earthquakes. Financial figures provided by UN-Habitat (2010) are indicative of the conditions in the country: High-quality and standard housing provided by the formal private construction sector is affordable only to the top $1 \%$ of the population. Serviced houses from the formal public housing programmes, which are 4-10 times cheaper, are affordable for the upper $20 \%$, but the capacity of the sector to deliver in large numbers is historically very limited and has never managed to cover the increasing demand. As a result, the majority of the households have to cover their housing needs by their own means and with limited access to loans and micro-financial tools. This informal private construction, which takes place sometimes even on formally planned (but rarely serviced) land and mostly on informal, traditionally allocated, non-serviced land, can provide houses about 60 times cheaper than the 
formal sector, but with an inevitable drop in quality. It is evident that under other pressing needs, it is not easy for Malawian households to invest in safety and preparedness against possible natural hazards, the return on which is only realised when a disaster occurs.

The recent publication of 'Safer House Construction Guidelines' (Bureau 2016), which were revised from the previous version prepared by the Government of Malawi in 2010 , is the first major step towards developing more resilient local communities/population against natural disasters. The guidelines are the outcome of joint efforts by the Government of Malawi (Department of Lands, Housing and Urban Development, Department of Buildings, Department of Disaster Management Affairs), the World Bank, the Global Facility for Disaster Reduction and Recovery (GFDRR), UN-Habitat and other international consultants, and now serve as a standard reference for the informal housing construction sector. The guidelines contain an overview of multiple environmental hazards in Malawi and adaptive procedures of site selection and house construction using locally-sourced materials (e.g. burnt bricks) and labour. They contain graphical explanations, ensuring that the methods are accessible to local artisans. Although the guidelines are based on current best practice, they are mainly qualitative and prescriptive, lacking quantitative evaluations of the improvements, and may be viewed as expensive solutions for local residents who struggle with financing these activities. Furthermore, the use of fired bricks, which has aggravated rapid deforestation and environmental degradation in Malawi and is therefore discouraged by the Government, may not be suitable from a sustainability viewpoint. Importantly, to improve the uptake of the guidelines in the local context, capacity-building programmes in local communities need to be promoted (e.g. International Federation of Red Cross 2011).

Currently, a gap exists between the actual and targeted characteristics of the building stock in Malawi, where the latter corresponds to those described in the Safer House Construction Guidelines (Bureau 2016). Due to the unaffordability or unavailability of materials and artisans to implement these recommended construction practices in local communities, a large population in Malawi may end up with some transitional phases in terms of housing (UN-Habitat 2010). This is because the majority of current informal housing stock does not meet the standards proposed by the Safer House Construction Guidelines, leaving a large population in vulnerable conditions. To promote the transformation of intransitional housing into more resilient permanent housing in multi-hazard environments, the building characteristics of the current housing stock in Malawi need to be understood more accurately.

As the first step towards the above goal, in Sect. 2, this study presents a literature review regarding existing international building classification schemes and seismic vulnerability assessment approaches. Subsequently, the current context of housing stock in Malawi is discussed in Sect. 3 from a structural (earthquake) engineering viewpoint. In Sect. 4, building classification criteria for Malawi as well as building survey methods are described. In Sect. 5, local characteristics of the current building stock in Central and Southern Malawi are investigated based on a building survey, which was conducted by the authors between 10th and 20th July 2017. The survey areas are susceptible to seismic hazard based on the tectonics around the southern part of Lake Malawi (Hodge et al. 2015; Chapola and Gondwe 2016; Goda et al. 2016). Important results of this work are that discrepancies between building stock information derived from global databases (e.g. Grünthal 1998; Jaiswal et al. 2011) and that obtained from the building survey reflecting the local built environment are identified, and that the influence of such discrepancies in building classification is quantified in terms of potential risk of building collapse during a severe earthquake. To demonstrate the latter, an example of seismic risk assessment is presented in 
Sect. 6 by focusing upon the 1989 Salima earthquake (Gupta and Malomo 1995; Chapola and Gondwe 2016). Finally, in Sect. 7, conclusions from this study are discussed by identifying the future research needs to achieve improved resilience of the housing stock against natural hazards.

\section{Literature review}

Earthquakes are a major cause of deaths. In developing countries fatalities are largely associated with the collapse of non-engineered masonry buildings (e.g. Jaiswal et al. 2011; So and Spence 2013; Lang et al. 2018). To mitigate seismic risk in developing countries, it is essential to assess the seismic risk of the current population and building stock (e.g. Chaulagain et al. 2015; Siddique and Schwarz 2015). This section presents a brief literature review of existing building classification schemes and seismic vulnerability assessment methods that are applicable to building stock in developing countries.

\subsection{International building classification scheme for earthquake risk assessment}

To assess the impact of earthquakes on any built environment, it is essential to know the structural systems of buildings and their expected performances and construction engineering standards, as well as the locations and distribution of vulnerable building stock in the affected area. International practice usually adopts building classification systems for different building typologies, according to the main structural characteristics, such as material, vertical load-bearing and horizontal load-resisting systems, connections between vertical (e.g. walls and columns) and horizontal structural elements (e.g. beams, floors and slabs, and roof structures). These typologies can be directly related to the expected performance of buildings during an earthquake and can be associated with a so-called 'seismic vulnerability class'. Moreover, other aspects of the earthquake damage impact (e.g. casualties, repair costs, and business interruption) can be included by adding more information on buildings, such as occupancy type (residential or non-residential) and geographical feature (urban or rural).

There are several building classification schemes that are applicable to international datasets, including the European Macroseismic Scale (EMS)-98 (Grünthal 1998), World Housing Encyclopedia (2019), Prompt Assessment of Global Earthquakes for Response (PAGER) (Jaiswal and Wald 2008), and Global Earthquake Model (GEM) (Brzev et al. 2013).

- EMS-98 is developed for building typologies that are prevalent in Europe. It describes how strongly an earthquake affects a specific building typology at a location of interest, and, as part of the EMS-98 scale, seismic damage of relevant building typologies is classified into seismic vulnerability classes defined to describe the consequences of a ground shaking (e.g. Abrahamczyk et al. 2013).

- WHE is an archival repository of housing construction practices and data in active seismic regions. The database adopts a uniform format to describe architectural and structural features, socioeconomic characteristics, seismic features, performance in past earthquakes, codes and construction practices, and known seismic strengthening techniques used in a particular country.

- PAGER operates on the basis of a global database of building inventories at a countryby-country level (Jaiswal et al. 2011), aiming at generating near-real-time post-earth- 
quake loss forecasts. PAGER's building database was developed by combining numerous sources: (1) United Nations' statistics, (2) UN-Habitat's demographic and health survey (DHS) database, (3) national housing census databases, (4) WHE database, and (5) other literature. However, the database lacks country-specific data for many countries, and some information was inferred from neighbouring countries (e.g. data from Tanzania were adopted for Malawi).

- The GEM building taxonomy is developed for characterising the earthquake risk exposure of buildings worldwide (as part of other initiatives of GEM). This is one of the most recent global efforts to describe and classify buildings in a uniform manner. The taxonomy builds on the existing knowledge base from other taxonomies, such as WHE and PAGER.

It is noteworthy that these international classifications are based on specific regions and rely on limited data, which are adopted to extrapolate classifications to other nearby regions, where data are not available. Since these extrapolations are usually based on expert judgment and lack of knowledge of the built environment in a specific region limits the possibility to validate these methods, the applicability of the global datasets may be difficult to be justified. In this regard, there are numerous studies that aim to develop local building classification schemes yet ensuring compatibility with international ones (e.g. Lang et al. 2013, 2018; Chaulagain et al. 2015; Siddique and Schwarz 2015).

\subsection{Seismic vulnerability assessment}

There are various seismic fragility assessment methods that are applicable to building classes. Many of them aim to assess buildings and their structural performance under earthquake loading at regional and national levels. Typically, these methods are based on so-called seismic fragility or vulnerability functions, and are pre-defined for building typologies located in specific regions (e.g. Calvi et al. 2006; D’Ayala et al. 2014). Some functions/models are developed based on statistical analysis of earthquake damage data in terms of fatality and structural damage/collapse (e.g. Jaiswal et al. 2011; So and Spence 2013), whereas others are based on analytical models calibrated against historical earthquake damage data. The use of these pre-defined fragility functions is highly favoured in developing countries, particularly when data to characterise building typologies and seismic damage from past earthquakes are not available, and hence there is no possibility to derive specific fragility curves based on local data. In this context, the building typology (or vulnerability class) signifies the seismic resistance and capacity.

Among the above-mentioned four international building schemes, EMS-98 and PAGER may be considered to be broadly applicable to Malawi (and other countries in East Africa). For instance, So and Spence (2013) developed their building collapse models based on EMS-98 seismic vulnerability classes A to E: weak masonry (A), unreinforced masonry (B), structural masonry or pre-code reinforced concrete frame (C), moderate-code reinforced concrete frame or shear-wall (D1), timber frame (D2), and steel frame or high-code reinforced concrete frame (E). The EMS-98 classification schemes lack the granularity in characterising local constructions. On the other hand, PAGER has developed its seismic vulnerability functions by expanding the types of building classes via expert elicitation/opinions (Jaiswal et al. 2011). Nevertheless, the underlying data are still lacking, and extrapolation of seismic vulnerability functions to other areas where there are hardly any damage data is necessary. 
Furthermore, since existing fragility assessment methods are often implemented to estimate seismic performance of engineered constructions, they are not directly applicable to non-engineered masonry buildings in developing countries, constructed with weak materials and under poor quality control, resulting in premature seismic failure. This underlines the need to review existing methods and identify among them the ones capable of striking the best balance in terms of: (1) inaccuracy due to limited or incomplete (global or local) data, adopted to characterise non-engineered building typologies, (2) ambiguity arising from partial (or a lack) information on how non-engineered constructions behave under seismic loads, in particular if seismic data from past earthquakes are not available, and (3) uncertainty arising from intrinsic randomness of the seismic phenomenon.

\section{Building characteristics in Malawi}

\subsection{Malawi building stock in the context of existing building classification systems}

In the household database of the Malawian 2008 National Census (National Statistical Office of Malawi 2008) dwellings were classified as: (a) 'traditional', made of rammed earth, daub and wattle or timber walls and lightweight thatched roofs, (b) 'semi-permanent', made of unburnt clay bricks and thatched roofs, and (c) 'permanent', made of burnt clay brick and iron sheet roofs. In practice, there are more intermediate combinations of 'traditional' and 'permanent' materials for walls and roofs. For example, timber and iron sheet roofs can be used with unburnt clay brick walls or thatched roofs with burnt clay bricks. But given that all the roofing systems used are flexible and lightweight, they are not fundamentally different from the structural viewpoint. Therefore the building classifications in this study are defined based on the masonry material. An inherent weakness of the above census classification is that it does not incorporate any structural information apart from the basic masonry material (e.g. there is no information about the mortar type).

Building typologies in Malawi have been investigated through literature review (e.g. Sassu and Ngoma 2002; Ngoma 2005; Bureau 2016) and the results of our own field surveys (Novelli et al. 2018; see Sect. 5). They are listed in Table 1, accompanied by short descriptions of the materials and main structural characteristics, the use in the housing sector, and their classification with respect to the most established international classification schemes, i.e. PAGER and EMS-98. Furthermore, the identified building typologies are rated within the vulnerability classes defined in the EMS-98 system, which are expressed in a reducing vulnerability scale from A (vulnerable) to $\mathrm{F}$ (resistant). The focus of this study is mainly on housing and especially on the most common typologies built by the informal construction sector, because they are the most vulnerable and cover the majority of the housing stock in Malawi.

In the context of the PAGER and EMS-98 classification systems, the above census housing types are represented by the typologies listed in Table 1:

- Traditional types RE (rammed earth) and W5 (wattle and daub). They can both generally described in the mud/adobe housing family, which is considered to be of high vulnerability (EMS-98: A)

- Semi-permanent types A (adobe blocks with mud mortar). Considering that the roof material does not have a significant impact on the structural behaviour (due to the generally light and weak structure), the most relevant PAGER subdivision for Malawi 


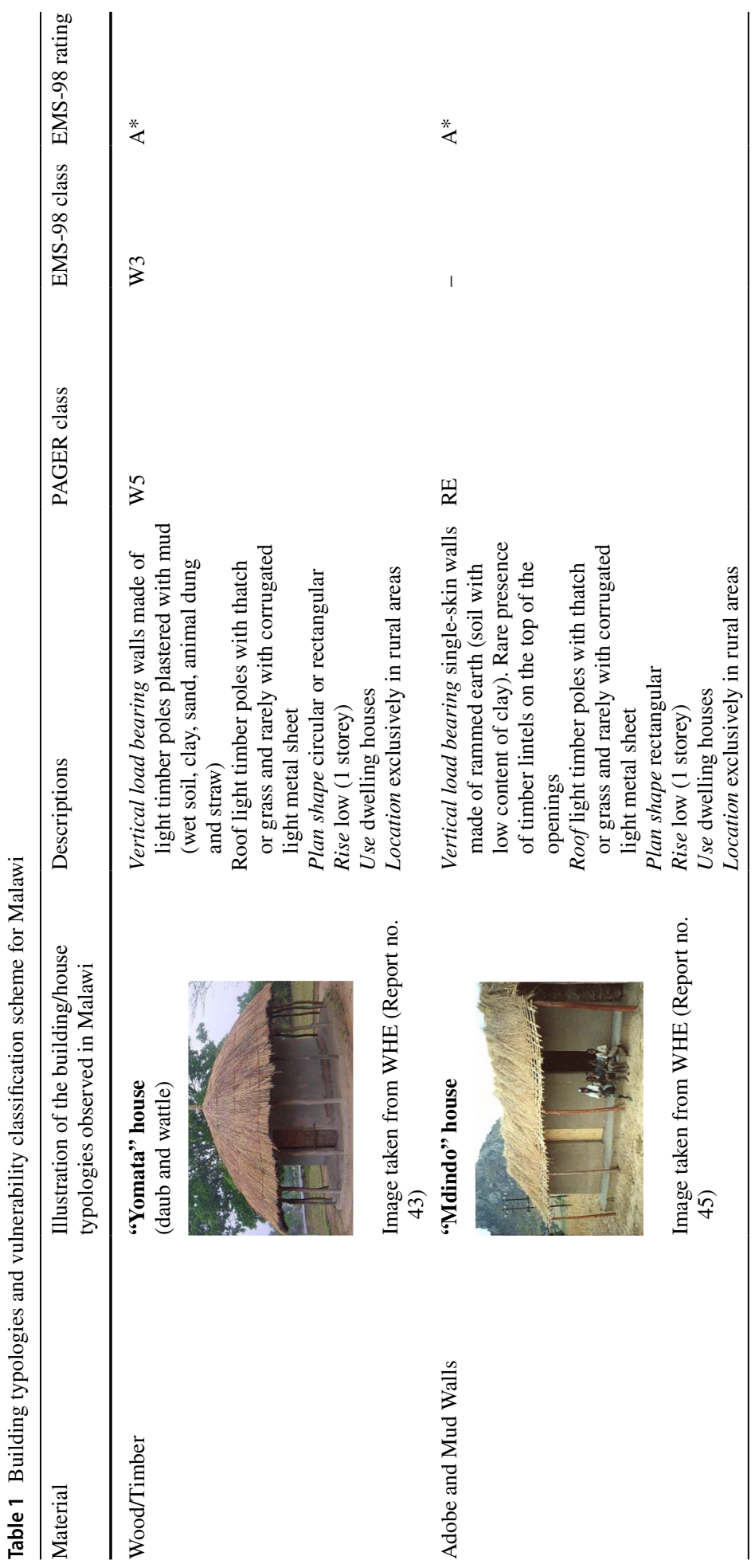




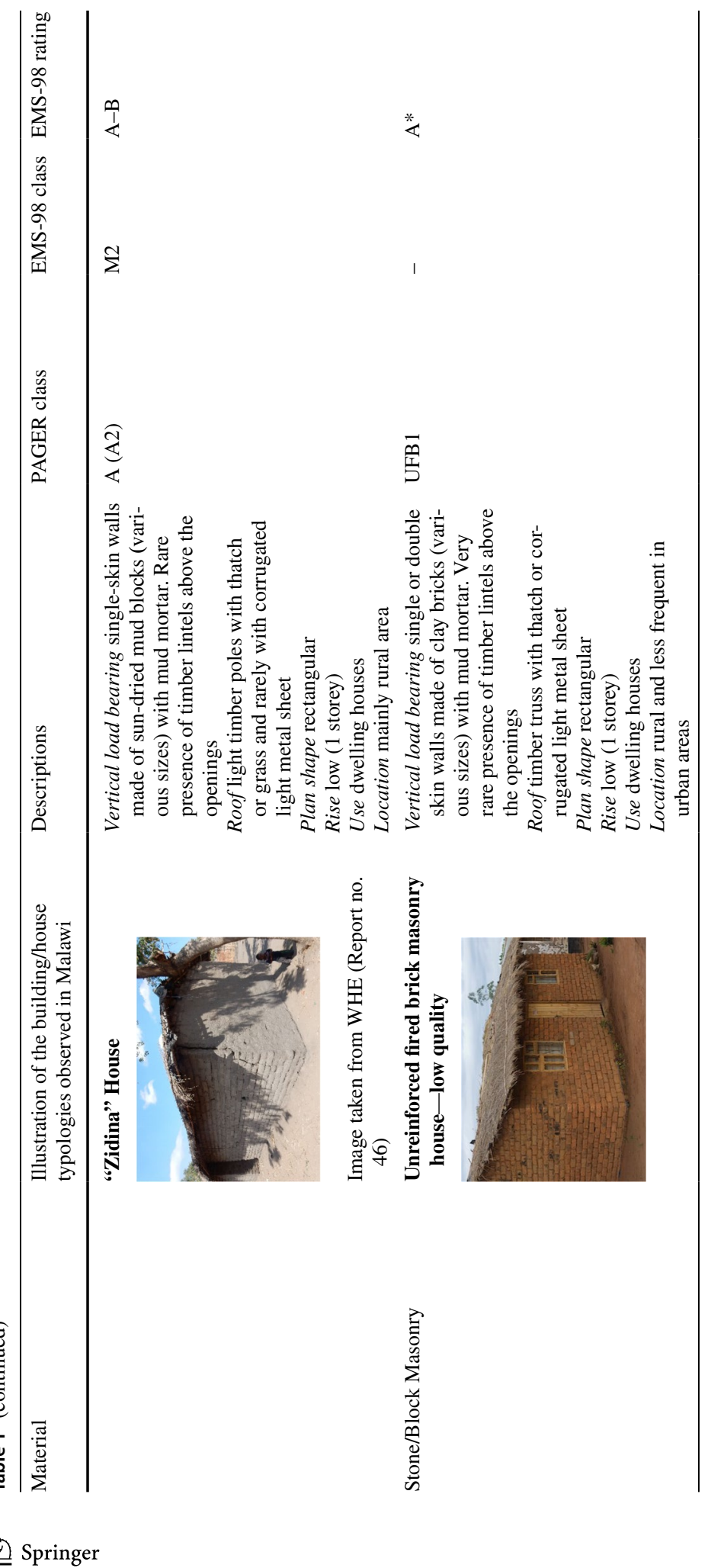




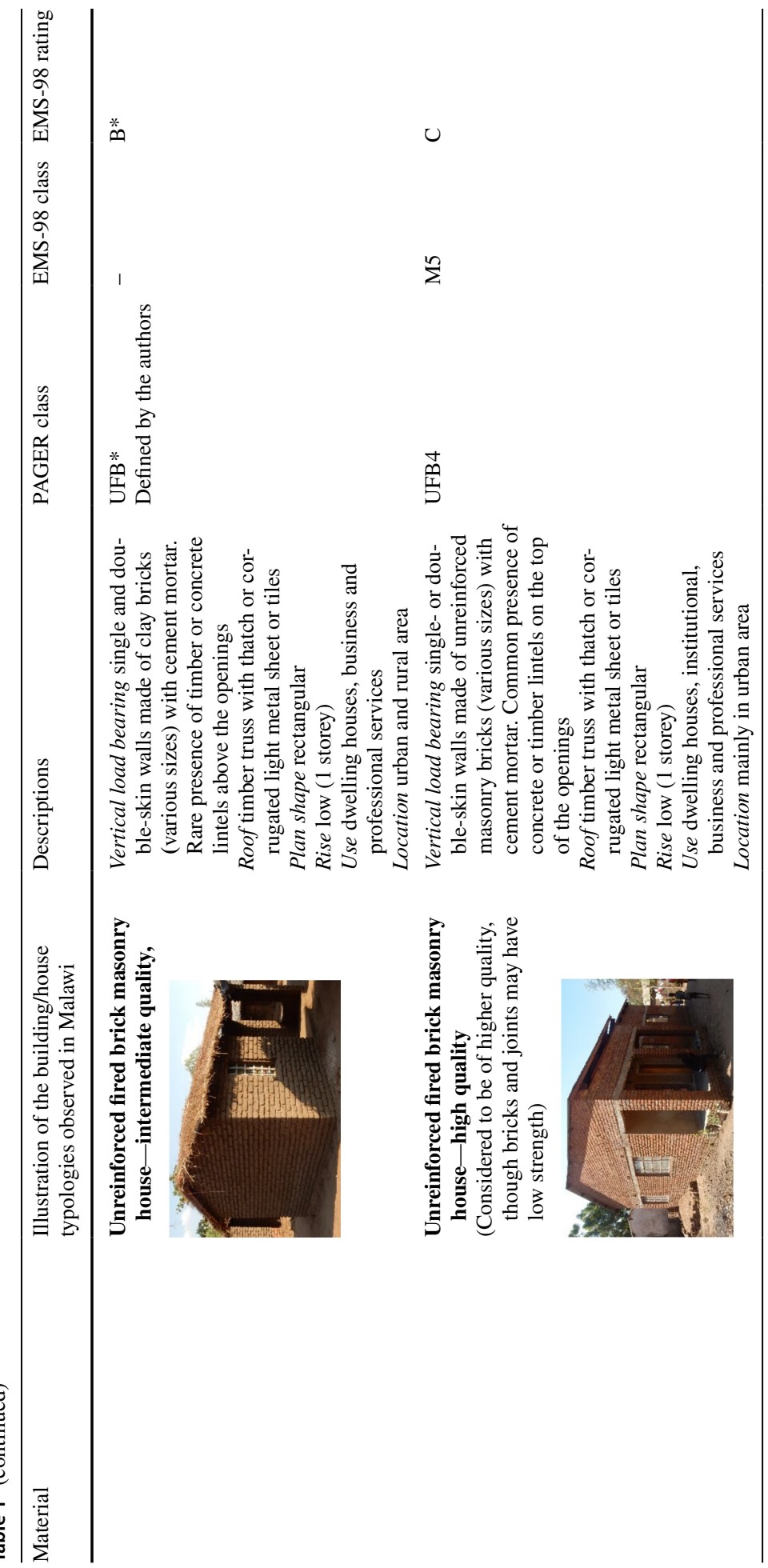




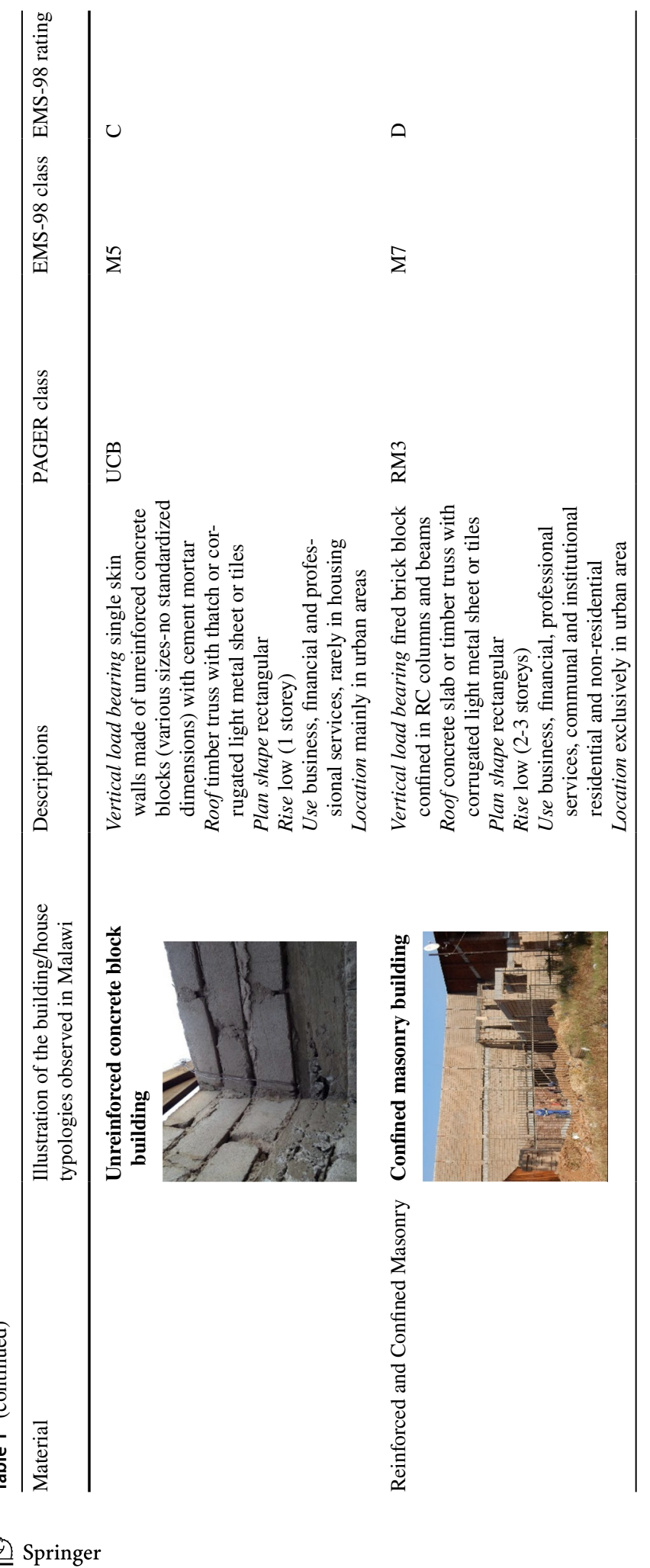




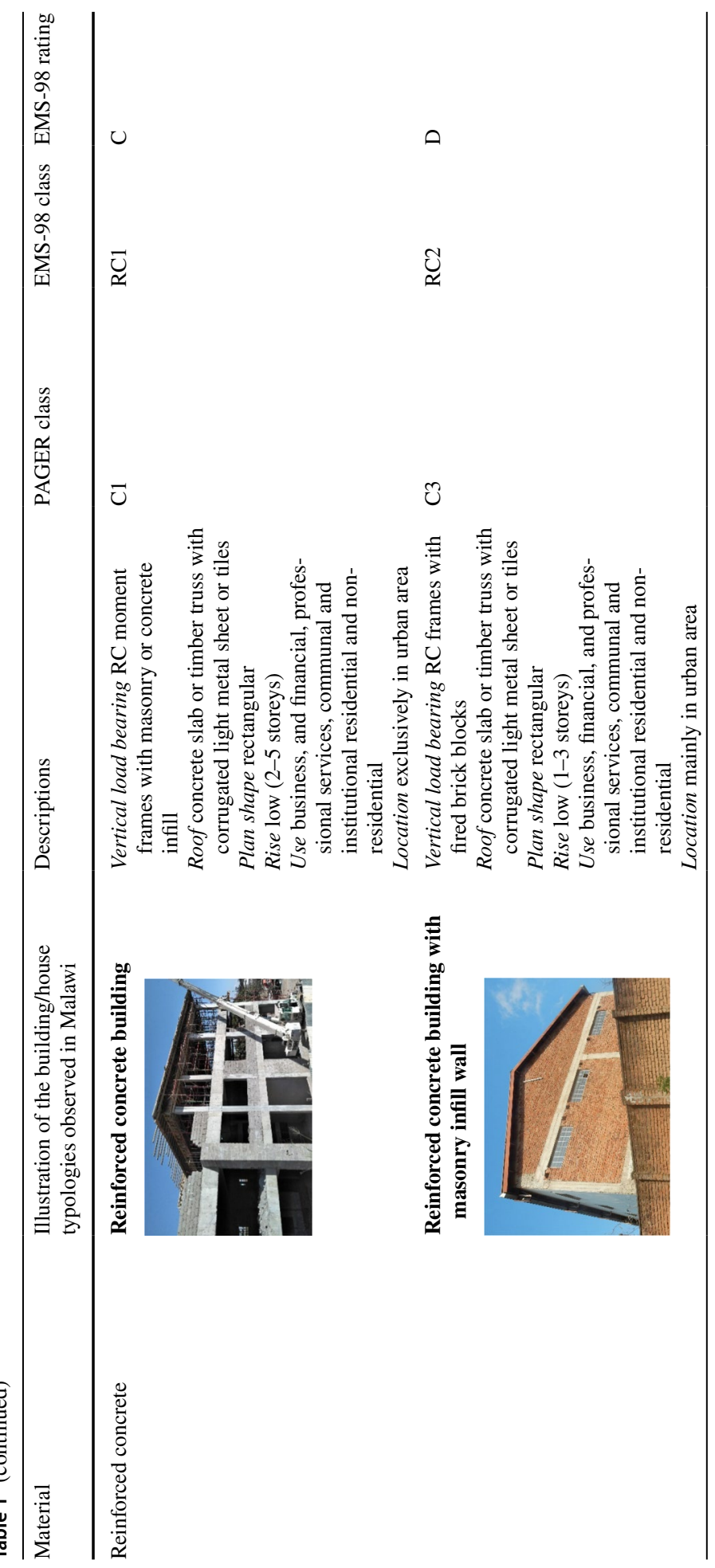




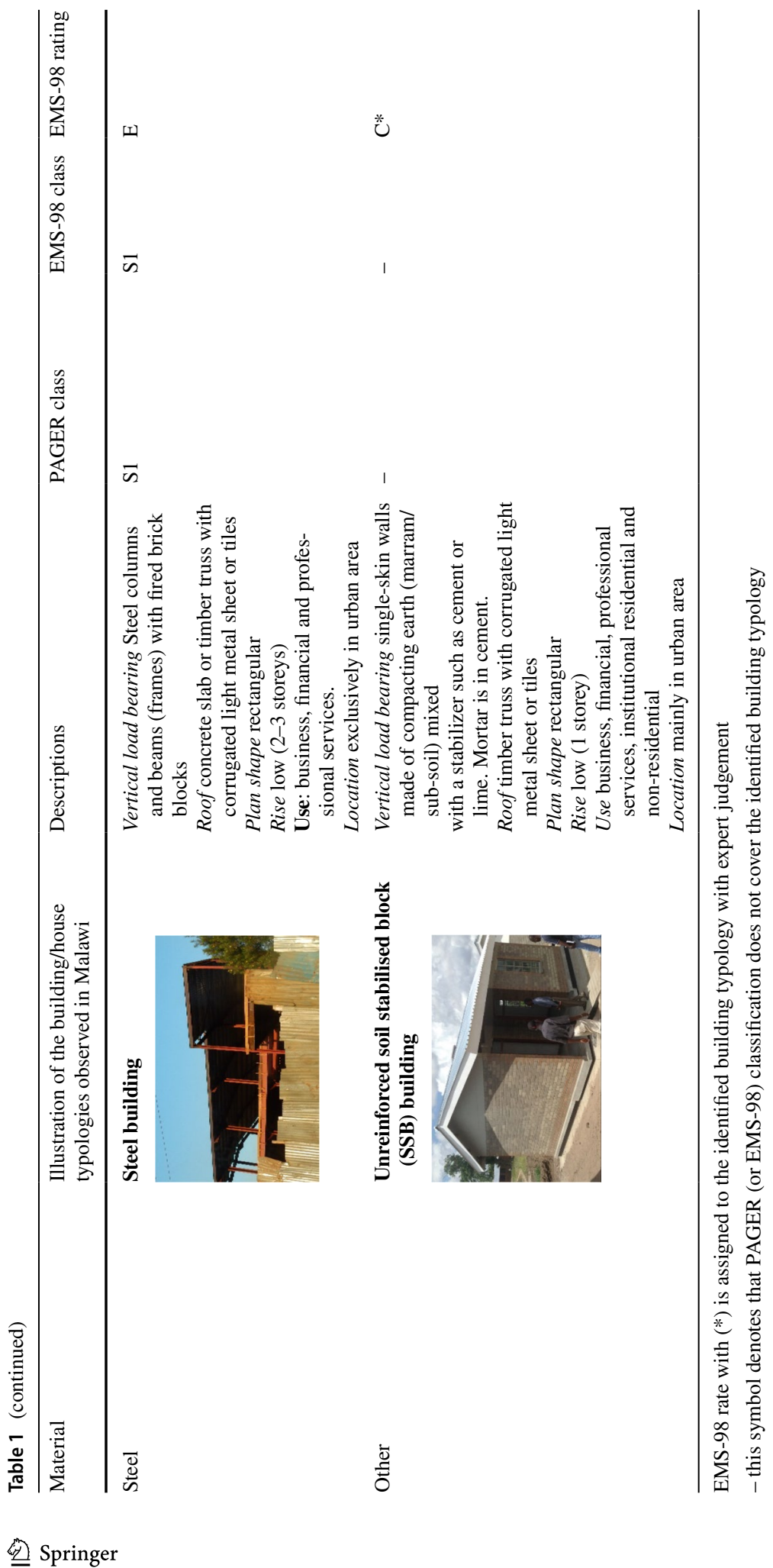


dwellings is $\mathbf{A 2}$ (adobe block, mud mortar, straw and thatched roof), even if the roof is made of light timber and corrugated iron sheets. This belongs to a high vulnerability class (EMS-98: A to B)

- Permanent types UFB (unreinforced fired brick masonry), subdivided into UFB1 and UFB4, for mud and cement mortar, respectively. The vulnerability of this class can significantly vary from high to medium (EMS-98: A to C), depending on the mechanical properties of the mortar material and the quality of the construction. Due to structural deficiencies (see Sect. 3.3), probably many buildings made of fired brick and cement mortar in Malawi are not qualified to be considered as UFB4, and a new intermediate vulnerability class may be necessary (see class UFB* in Table 1).

\subsection{Discrepancies between global and local datasets of Malawi building stock}

The next important step is to obtain reliable information of proportions of structures in individual building classes. However, estimating the proportions in the building stock involves considerable uncertainty. This is evident from the information available in the literature.

- WHE Three entries for Malawian housing typologies are available in the database. Sassu and Ngoma (2002) indicated that $35 \%$ and $45 \%$ of houses can be classified as rammed earth and unburnt brick wall buildings, respectively, whereas $5 \%$ of the building stock is wattle and daub; the remaining $15 \%$ is unclassified and assumed to be fired brick. The data were based on the 1998 census.

- 2008 Malawi census The proportions of traditional, semi-permanent, and permanent dwelling types were $28 \%, 44 \%$, and $28 \%$, respectively, with huge variation between urban and rural areas. These statistics are available at national and regional levels (note: at the time of writing, the most recent information based on the 2018 census is not yet available).

- PAGER Structural types that are assigned to Malawian buildings are: mud walls (M2mud walls with horizontal wood elements; this is not included in Table 1, since it is not met in Malawi), adobe blocks (A), rubble stone (RS; this is not defined in Table 1, since it is rarely met in Malawi), unreinforced fired brick masonry (UFB), and unreinforced concrete block masonry (UCB), with proportions of $15 \%, 19 \%, 1 \%, 14 \%$, and $51 \%$, respectively. No distinction was made for urban versus rural and for residential versus non-residential use. These values were assigned based on expert judgement and the building stock of the neighbouring country of Tanzania, estimated based on the UNHabitat 2007 global report using data from the 2004 National Census in Tanzania. As a result, this dataset was treated as 'low quality' in PAGER (Jaiswal and Wald 2008).

To demonstrate the discrepancy of the available information regarding the housing stock in Malawi, key features of the building information from the three sources are compared in Fig. 1. To facilitate the comparison, results for each source are grouped in the same three categories according to the Malawi Census dataset. The estimates based on the 2017 building survey have been also added for comparison (see Sect. 5). The WHE dataset, relying on the 1998 census data and expert judgement (Sassu and Ngoma 2002), is comparable to the 2008 census data, but there is clear evidence of changes in housing conditions over the years; this is consistent with the UN-Habitat (2010) report, which indicates that housing conditions have changed rapidly in Malawi, traditional/semi-permanent houses being replaced with more permanent ones. On the other hand, there are considerable differences between the census and 


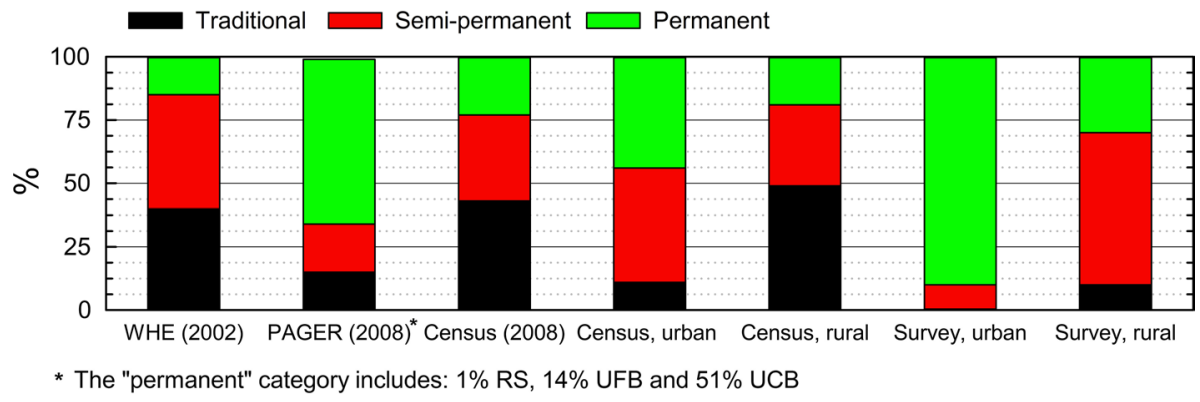

Fig. 1 Comparison of housing stock information from the WHE (Sassu and Ngoma 2002), PAGER, the 2008 Malawi Census, and the 2017-survey estimates discussed in Sect. 5. The colour-coded categories of traditional, semi-permanent, and permanent building classes are based on the 2008 Malawi Census

PAGER inventory datasets, both in terms of materials and typologies considered, as well as the insensitivity of the PAGER dataset to different building inventories observed in urban and rural areas. Although PAGER and the 2017 building survey give similar high percentages of permanent structures, there is a huge difference in the seismic vulnerability of the building typologies that are categorised as 'permanent' in the two datasets.

\subsection{Discrepancies between global vulnerability models and actual Malawi housing stock characteristics}

Apart from the differences in the identified typologies and the percentages of buildings classified in them, Malawian housing structures exhibit particular characteristics, which can add more uncertainty to earthquake disaster impact predictions based on the global vulnerability models. Malawian housing structures predominantly consist of one storey with lightweight roofs, so only small horizontal actions need to be sustained by the load-bearing elements of the structures. On the other hand, the walls are made of poor quality materials and are slender; they generally lack good connections between intersecting load-bearing walls (wall corners and T-junctions) and between walls and roofs, increasing the risk of collapse in out-of-plane failure patterns. Moreover, most of the openings are usually not supported by lintels, the roof structures are flexible and the foundations are poor, resulting in settlement and cracking. On occasion, there were cases witnessed in the 2017 survey where the quality of the masonry was too poor to support its self-weight or the weight of a heavy concrete lintel. Typical examples of structural deficiencies of Malawian structures are shown in Fig. 2.

\section{Methodology for building surveys and classification}

\subsection{Local building classification and related differences with global building classifications}

The local building characteristics in Malawi differ in detail from global ones (Sect. 3); there are clear discrepancies in terms of building typology classifications and vulnerability. These differences in building characteristics contribute to inherent vulnerability of Malawian houses. The PAGER-based building classes and corresponding seismic 

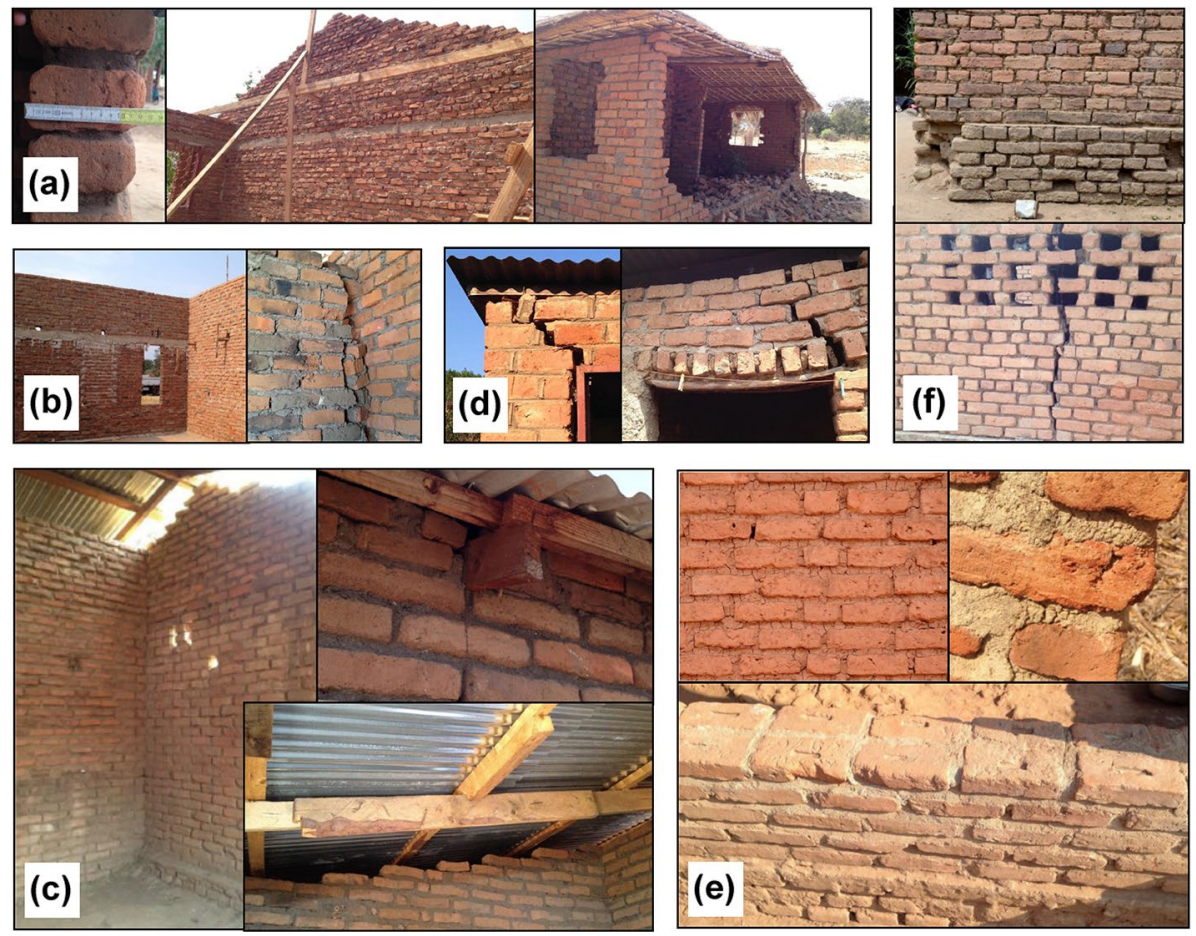

Fig. 2 Structural deficiencies of Malawi housing construction: a slender walls and unsupported gables, b weak connections between internal and external walls, c absence of ring beam/wall plate and horizontal ties, poor fixing, $\mathbf{d}$ weak pier cracked by the rafters of the roof-absent or insufficient lintels, e weak mud mortar, thick $(>20 \mathrm{~mm})$ and uneven joints, no header bonding, $\mathbf{f}$ top: erosion of walls and loss of bricks, and bottom: cracks due to differential settlement of foundation (image courtesy: TNM Bureau, Safer House Construction Guidelines, 2016)

vulnerability functions may not be suitable for representing seismic vulnerability of residential houses in Malawi. To assess earthquake risk impact to Malawi, reliable local data for both buildings and associated structural fragilities are essential.

To obtain realistic estimates of proportions of the main building classes identified for housing construction in Malawi, the authors conducted a building survey in Central and Southern Malawi between 10th and 20th July 2017. The survey methods are explained in Sect. 4.2. The building classification scheme that is adopted is an amalgam of the local and international methods, more specifically the Malawi census-based method (i.e., traditional, semi-permanent, and permanent) and the PAGER-based seismic vulnerability method (see Sect. 3.1 and Table 1). The rationale for this hybrid approach is to bridge the gap between the local and global schemes.

To demonstrate that it is important to examine the differences of seismic vulnerability models based on global/local building classifications, a risk assessment study is performed for the Salima earthquake case with reference to the method discussed in Sect. 4.3. The case study aims at highlighting the discrepancies between the risk assessment results obtained using global and local building classifications. 


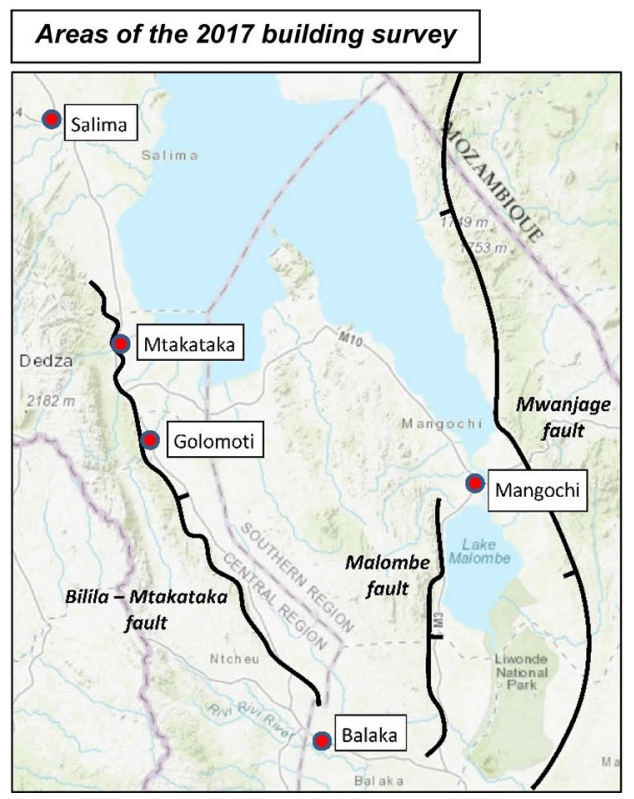

Selection of 2008 Census

Enumeration Areas (EA)

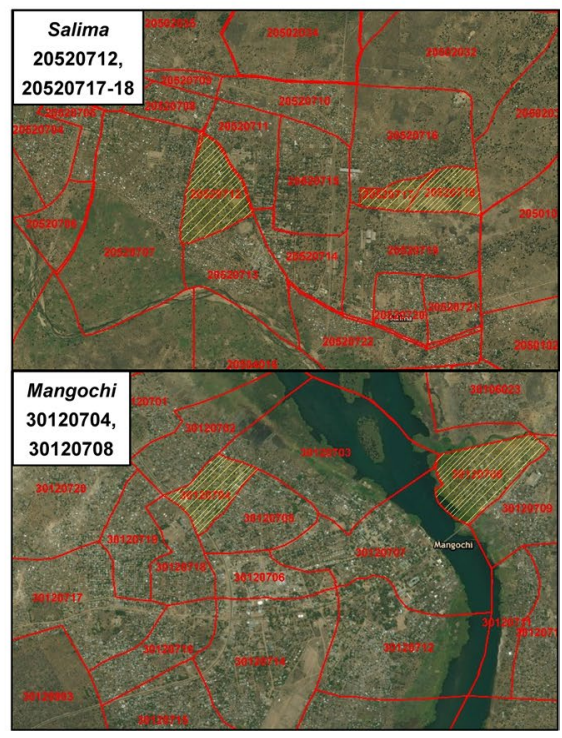

Fig. 32017 building survey locations and selected enumeration areas based on the 2008 census. In the figure, major earthquake faults are indicated by thick lines, whereas the survey locations are indicated with circles. The base map for Central and Southern Malawi and the satellite images for enumeration areas in Salima and Mangochi were acquired from ArcGIS ${ }^{\circledR}$ and ArcMap ${ }^{\mathrm{TM}}$ base map and World Imagery database by ESRI

\subsection{Survey methods for building classification criteria}

Prior to the survey, demographic features of the target areas, such as population and household numbers, were gathered from the 2008 census. Eight Enumeration Areas (EA, which is a basic geographic area unit in the census, normally containing a few hundred to one thousand houses), were selected as representative sub-areas by combining population/household numbers from the census and satellite images, in ArcGIS ${ }^{\circledR}$ platform. They were chosen such that different cities/townships as well as different built environments, from urban to rural, were captured. The eight EAs covered five different locations: Salima, Mtakataka, Golomoti, Balaka, and Mangochi (Fig. 3). All the selected locations are secondary-urban district centres and small townships/market towns, which are less developed in comparison with major urban cities in Malawi, such as Lilongwe, Blantyre, and Zomba, but are more developed than pure rural villages. From seismic hazard perspectives, Salima suffered significant damage from the 1989 earthquake (Chapola and Gondwe 2016), whereas Mtakataka, Golomoti, and Balaka are located along the Bilila-Mtakataka fault (Jackson and Blenkinsop 1997), where the potential seismic risk is high (Goda et al. 2018). Mangochi is located near the Mwanjage fault (Flannery and Rosendahl 1990) and the Malombe fault. Because the areas covered by the survey were limited due to the available resources, the results are not intended to generate a complete and comprehensive building stock database for the country. Rather, they should be used as supplementary information 

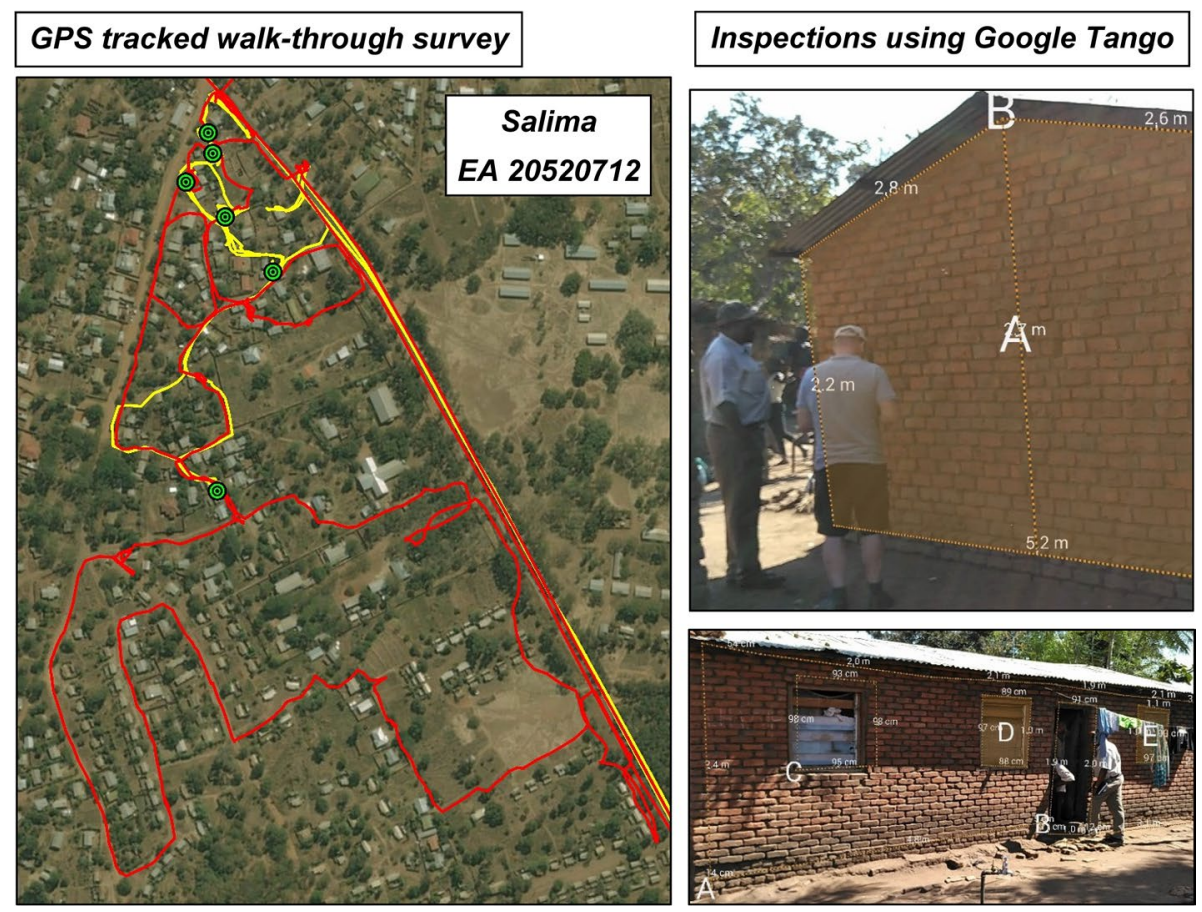

Fig. 4 Quick walk-through survey and detailed building inspections in Salima (EA20520712). On the lefthand side image, red lines correspond to GPS tracks during the quick walk-through survey, whereas yellow lines correspond to GPS tracks during the detailed surveys, marked with green circles. Figure was produced using $\operatorname{ArcGIS}^{\circledR}$ software and ArcMap ${ }^{\mathrm{TM}}$ World Imagery satellite base map by ESRI. (Color figure online)

to modify the existing comprehensive data (e.g. national census) considering current rapid demographic changes in Malawi (UN-Habitat 2010).

In each EA, two different types of building surveys were conducted: (1) quick walkthrough survey to count and classify all buildings in the EA and (2) detailed surveys of individual buildings. Examples of the walk-through and detailed surveys of individual buildings are presented in Fig. 4 for one of the census areas, EA 20520712, in Salima. Buildings were classified with reference to the 2008 census system, based on wall material types: (1) mud (traditional), (2) unburnt brick (UB, semi-permanent), and (3) fired brick (FB, permanent). In addition to that, they were classified in terms of other structural characteristics that contribute to seismic vulnerability: wall thickness (single-skin or double-skin walls), the presence of lintels above openings and their type (timber, concrete or concrete ring beam), shape of building layout (regular or irregular), and roof shape (monopitched, gable or hipped). Single-skin walls typically have a thickness of 10-15 cm (corresponding to the shorter side of typical bricks in Malawi), whereas double-skin walls have a thickness of 20-25 cm (corresponding to the longer side of typical bricks in Malawi).

The detailed surveys of individual buildings aimed to collect more structural engineering details, such as additional material information (e.g. mortar type), building dimensions in plan and in elevation (e.g. side walls and gable wall heights), geometrical factors affecting the strength of the masonry (e.g. brick sizes and bonding, thickness of the walls, and thickness of the mortar joints) and the quality of the structure overall (e.g. opening layout 
and dimensions, presence of lintels above the openings or ring beams at the roof level, layout of internal walls and quality of connections, and foundation conditions). A few representative buildings or archetypes within each EA were selected for detailed inspections and measurements (16 overall). Internal and external dimensions were measured using a laser instrument, tape, and a Lenovo ${ }^{\mathrm{TM}}$ tablet device equipped with Google Tango augmented reality technology (i.e. quick photographic survey; see Fig. 4). Subsequently, relevant material/structural details were recorded on bespoke survey sheets and detailed drawings of the surveyed buildings were produced, to be used successively in numerical modelling of the inspected structures.

In addition, a quicker semi-detailed survey was implemented in Mtakataka and Balaka to identify external building dimensions of 1 in every 5 buildings (52 buildings inspected overall) and to record information related to structural characteristics (e.g. masonry type, roof type, shape regularity, regularity of openings and piers, and type of lintels supporting the openings). The areas of the semi-detailed surveys were only part of those for the walk-through surveys in the selected areas. An overall quality rating of the building conditions with respect to materials, maintenance and structural deficiencies was also assigned to these houses.

\subsection{Comparison of seismic risk assessment based on global and local building classifications}

It is important to examine the differences between the global/local building classifications and their impacts on the seismic risk assessment. To this aim, a risk assessment study is specifically performed for the Salima earthquake case, using building classification and vulnerability models (fragility functions) based on PAGER and building exposure derived not only from PAGER but also from our local surveys (Sect. 5).

The seismic vulnerability models based on PAGER adopt empirical seismic fragility functions for building collapse as a function of modified Mercalli intensity (MMI). The functional form of the fragility function, i.e the probability of failure for a given earthquake intensity, is given by:

$$
P_{c}=a 10^{b /(\mathrm{MMI}-c)}
$$

where $a, b$, and $c$ are the model coefficients that were obtained from regression analyses of empirical MMI-seismic damage data.

Although MMI is a common seismic intensity parameter, it may be more convenient to express seismic fragility functions in terms of peak ground acceleration (PGA). For lowrise masonry buildings, PGA is a good choice as these structures tend to have short vibration periods (Goda et al. 2018). This can be done by using the MMI-PGA conversion equation by Wald et al. (1999), which is adopted for the PAGER systems:

where PGA is in $\mathrm{cm} / \mathrm{s}^{2}$.

$$
\mathrm{PGA}=10^{(\mathrm{MMI}+1.66) / 3.66}
$$

Furthermore, to facilitate the seismic fragility analysis, the PGA-based seismic fragility curves are approximated by using a popular lognormal model:

$$
P_{c}=\Phi(\log (\mathrm{PGA} / \mu) / \sigma)
$$

where $\Phi$ is the standard cumulative normal distribution function, and $\mu$ and $\sigma$ are the mean value and logarithmic standard deviation (dispersion) parameters. 
To demonstrate the effects of taking into account realistic a building classification scheme in seismic risk assessment, 1000 probabilistic earthquake scenarios based on the source parameters of the 1989 Salima earthquake were generated by implementing earthquake source scaling relationships (see Goda (2017) for details of Monte Carlo simulations of probabilistic earthquake scenarios). To simulate seismic shaking intensities at $0.02^{\circ}$ by $0.02^{\circ}$ grids (approximately $2 \mathrm{~km}$ by $2 \mathrm{~km}$ ) cells for a given earthquake scenario, the ground motion prediction equation by Boore et al. (2014) was used together with a spatial correlation model to simulate realistic ground motion random fields (see Goda et al. (2018)). To account for the local near-surface soil conditions (which affect the ground shaking intensity due to site amplification), the so-called Vs30 (average shear-wave velocity in the uppermost $30 \mathrm{~m}$ ) database was considered (Wald and Allen 2007). Using the above methods and models, 1000 probabilistic shake maps for the Salima earthquake were generated. The results of the seismic risk assessment are discussed in Sect. 6.

\section{Building survey in central and Southern Malawi}

\subsection{Walk-through survey results}

The results of the quick walk-through survey are summarised in Fig. 5. The number of buildings identified in the survey in most EAs was generally in agreement with the number of households recorded in the 2008 census, even though a household might occupy multiple dwelling structures. Other possible sources of differences could be: (i) non-residential buildings were included in the building count, (ii) actual boundaries of the EAs differ from those shown in the 2008 census, and (iii) inspectors' errors, such as double-counting, might have occurred. It is also reasonable to assume that the number of buildings in some of these areas may have increased since 2008 due to urbanisation. Overall, it appears that the recorded percentages of the different building typologies are reliable for drawing useful observations regarding the current conditions of the housing stock in the surveyed areas.

Grouping together the surveyed locations that exhibit similar proportions of the same building typologies, three distinct types of areas can be identified: Group 1: 'secondary-urban areas including buildings from the formal construction sector' (Salima 20520712); Group 2: (ii) 'secondary-urban areas developed by the informal construction sector' (Salima 20520717 and 20520718, Mangochi 30120704 and Balaka 31220704), and Group 3: 'sub-urban areas and rural townships/market town areas' (Mangochi 30120708, Golomoti 20807805 and Mtakataka 20807802). The average results for the three groups are presented in Fig. 6.

Compared with the 2008 census data described in Sect. 3.1, the results indicate that the proportions of permanent buildings (i.e. fired brick masonry) in the surveyed areas are significantly greater than those indicated in the census data. The characteristics of the housing stock, especially in urban areas, have changed since 2008, moving towards the permanent housing type, made of fired clay bricks. The percentages of the traditional housing type in all areas were negligible, around $1 \%$ or less (these counts are included with those for the unburnt bricks in Fig. 6). The percentages of traditional buildings in secondary-urban areas in Central and Southern Malawi were found to be smaller than the previously estimated national average (Ngoma 2005; UN-Habitat 2010). They remain in rural areas, but their percentages are decreasing continuously (e.g. from $71 \%$ in the 1998 census to $43 \%$ in the 2008 census), since new structures are predominantly made of fired or adobe bricks. 


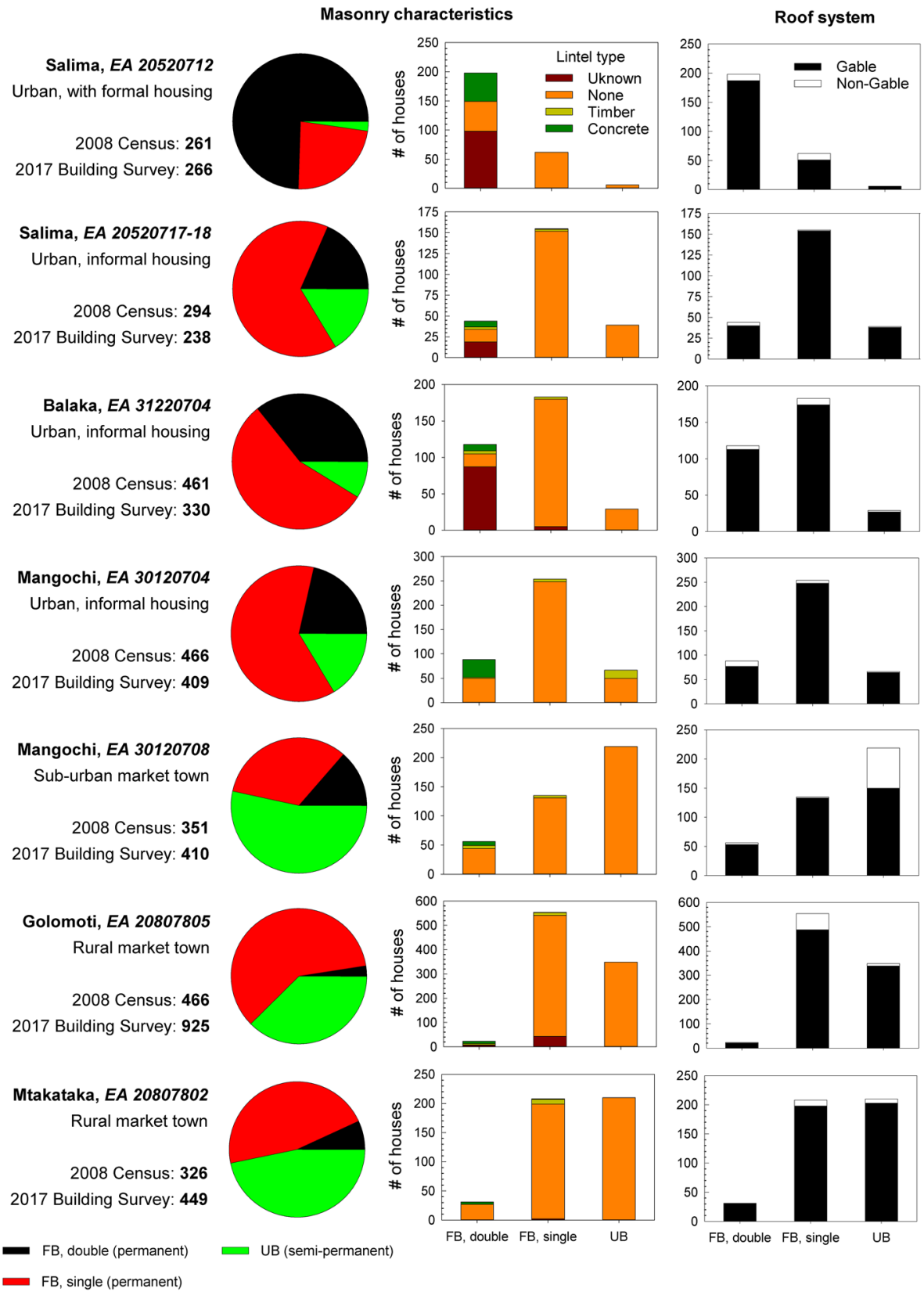

Fig. 5 Summary of quick building survey results per enumeration area. The numbers of households in the 2008 census and the surveyed houses in 2017 are indicated on the left-hand side; in the pie charts, the numbers of permanent (double-skin), permanent (single-skin), and semi-permanent houses are shown; in the bar graphs (second from the right), the numbers of different vertical load-bearing systems are shown; and in the bar graphs on the right-hand-side, the numbers of different roof systems are shown 


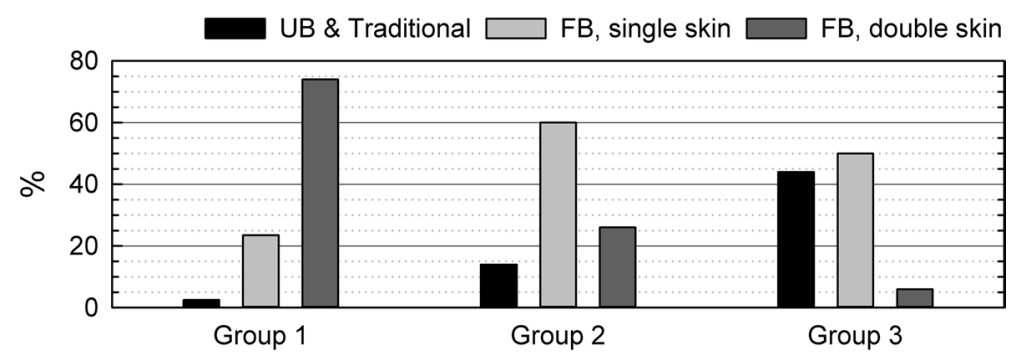

Fig. 6 Results of the 2017 building survey, summarised per area group. Group 1, 2, and 3 correspond to 'secondary-urban areas with presence of formal construction sector', 'secondary-urban areas developed by the informal construction sector', and 'sub-urban areas and rural townships/market town areas', respectively

In most areas, $50 \%$ to $60 \%$ of the permanent-type structures were built with single-skin walls. According to the Safer House Construction Guidelines (Bureau 2016), single-skin walls are not recommended nor regarded as earthquake resistant. With the small exception of structures built with larger size bricks of about 14 to $15 \mathrm{~cm}$ width, the majority of the single-skin walls were weak and slender, exceeding the limit for slenderness (height/thickness) ratio of 20, according to the Malawi code of practice MS791-1:2014 (Malawi Bureau of Standards 2014).

Opposed to the Safer House Construction Guidelines, openings in the masonry were poorly supported; less than $20 \%$ of the inspected buildings had proper lintels. The presence of ring beams and wall plates to provide additional confinement to the masonry, in combination with the fixing of the roof structure, was rare. Cases classified as 'unknown' lintel type in Fig. 5 pertain to those where it was not possible to confirm the existence of lintels due to rendering on the walls. Judging from the conditions prevailing in the neighbouring structures, many of the 'unknown' lintel cases in the formal construction urban areas (e.g. Salima 20520712) are probably concrete or timber, whereas in all other areas, most of the unknown cases seem likely to have no lintels.

Even though they are identified as vulnerable elements and are not recommended in the Safer House Construction Guidelines, gable roofs were used in more than $80 \%$ of the dwellings (Fig. 5). Unsupported masonry gables tend to fail in the out-of-plane direction, when they are subjected to strong ground shaking. An alarming observation was that the majority of new structures are using this roof type for practical reasons; current construction practice finds it easier to fit gable roofs on rectangular houses because of the simpler roof structure (i.e. support a ridge beam on the tops of the gables and span rafters from the ridge beam to the side walls) and because of the increased use of rectangular corrugated iron sheets. On the other hand, smaller, circular or square-shaped traditional and semi-permanent houses quite often had hipped lightweight thatched roofs. From the seismic vulnerability perspective, the Government's subsidy programme to promote the use of corrugated iron roofs, which are beneficial for shelter from rain, might have caused a negative side effect. The percentages of properly constructed timber roof trusses (be they for gable, hipped or monopitch roofs) were very small.

Seismic vulnerability due to irregular building shapes was found to be low, since more than $75 \%$ of dwellings were found to be rectangular with acceptable building aspect ratios, i.e. ratio between (representative) longer and shorter sides of a building footprint, of 3:1 or less (Arya et al. 2014); more details on the building layouts are provided in Sect. 5.2. The above numbers do not include seemingly dangerous extensions, such as heavy-weight porches and roof extensions on isolated pillars, which were quite common in the surveyed areas. 


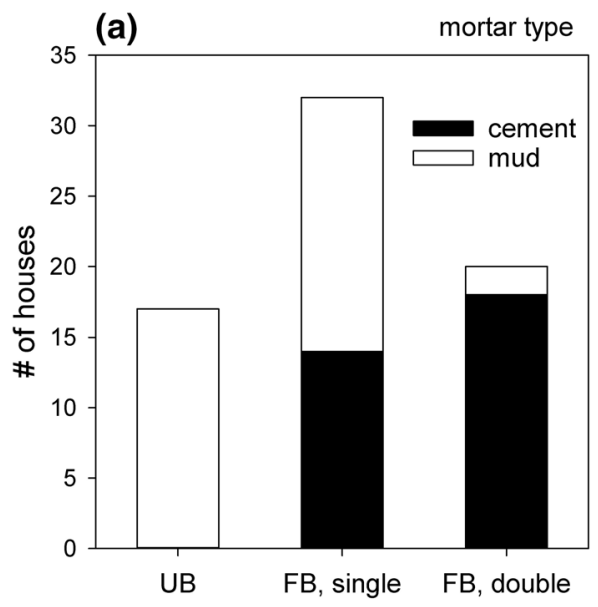

(b)

Dwelling dimensions

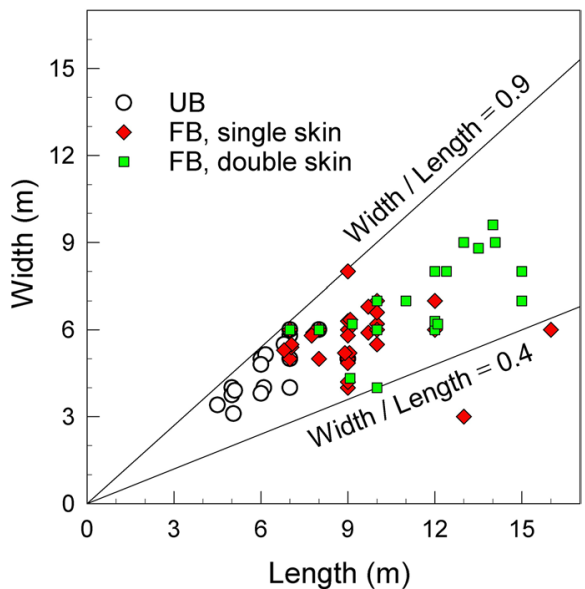

Fig. 7 Summary of results from detailed and semi-detailed building surveys. a Shows bar plots of the mortar types observed during the surveys, whereas b shows the building footprint dimensions for different building types

\subsection{Detailed and semi-detailed survey results}

In Fig. 7, the main findings of the detailed and semi-detailed surveys are summarised. On the bar chart in Fig. 7a, the combinations of various materials used for each masonry type can be observed; semi-permanent (UB) houses are exclusively built with mud mortars and double-skin permanent (FB) houses are mainly built with cement mortars. Single-skin permanent houses might have either cement or mud mortars with almost equal percentages. The use of single-skin walls or the occasional use of cement is apparently related to the limited resources of the household, thus double-skin buildings are less popular and the use of mud mortar is generally frequent in poorer urban and rural areas. The financial restrictions of households are apparently affecting the quality of the cement mortars, i.e. use of less cement in the mortar mixture, which dramatically decreases the strength of the masonry. The information about mortar type and strength is important from a vulnerability perspective, but it was not possible to be thoroughly collected during this survey.

In Fig. 7b, relationships between building layouts and dimensions are presented. First, the width/length aspect ratios are generally bounded between 0.4 and 0.9 , decreasing with increasing length. Smaller dwellings tend to be closer to a square layout, which becomes more rectangular as the building size increases. Overall, these aspect ratios are considered as regular from the seismic performance perspective (Arya et al. 2014). Second, there is a strong correlation observed between building materials and house dimensions. Houses made of unburnt bricks and mud mortar, are naturally smaller, normally up to $7 \mathrm{~m}$ long. Single-skin houses made of fired bricks and cement mortar are mainly between 7 and $10 \mathrm{~m}$ long, whereas the vast majority of buildings exceeding $10 \mathrm{~m}$ in length are double-skin.

The use of fired bricks and cement mortar often leads to larger, more spacious building layouts to accommodate the trend of increasing living standards. On the other hand, the use of longer and higher walls with more and larger openings can also result in higher seismic vulnerability, especially when the building standards and quality do not increase accordingly. This is a very serious vulnerability factor, in light of poor overall ratings of 
structural quality and damage/maintenance conditions: more than 50\% of the inspected buildings exhibited signs of structural damage caused by low quality masonry, irregularity in the openings, absence of lintels, poor roof structure, settlement of foundations, signs of erosion/scouring and insufficient mitigation measures and maintenance.

Based on the foregoing, it can be concluded that seismic vulnerability of Malawian structures cannot be based solely on the wall material or the masonry type. For example, it may be too simplistic to consider that all permanent houses or even all double-skin permanent houses are safer than others. The classification of buildings and the assignment of seismic vulnerability class are complex and involve judgement; on the one hand, all the masonry housing types in the country look simple and relatively similar, but on the other hand the huge variety of construction materials and construction quality drastically affects the fragility of the houses. In this regard, the building characteristics obtained from the surveys are useful for improving our understanding of the building performance under intense ground shaking.

\subsection{Comparison of the global and local building stock data}

Based on the survey results presented in Sects. 5.1 and 5.2, the percentages of houses are estimated as follows:

(a) In urban areas, the estimations are based mainly on Group 2, given that the formal sector represents less than $10 \%$ of housing construction (UN-Habitat 2010). Based on the survey data in Fig. 5, overall it is estimated that $10 \%$ of the housing stock are classified as semi-permanent (A); 60\% are fired brick—single-skin, half of which have mud mortar (UFB1) and the other half have cement mortar (UFB4); $30 \%$ are fired brick-double-skin with cement mortar (UFB4). In short, for urban areas, the overall building proportions of $10 \%, 30 \%$, and $60 \%$ can be assigned to PAGER-based building classes A, UFB1 and UFB4 respectively.

(b) In rural areas, given that pure-rural areas were not surveyed, the estimations rely on the results for sub-urban areas and rural market towns (Group 3), which are expected to lie somewhere between urban and pure-rural conditions. The following considerations can be made based on our survey: fired brick—double-skin buildings are rarely met; there is a clear majority of adobe structures, i.e. $60 \%$ adobe (A) versus $30 \%$ fired brick, the latter split again approximately in half between the sub-classes with mud and cement mortar (UFB1 and UFB4, respectively); the proportion of traditional houses (i.e. rammed earth, timber and mud) has been dropping. Assuming the proportion has continued to reduce at a similar to that between the previous two censuses (i.e. $71 \%$ in 1998 and $43 \%$ in 2008) it can be inferred to be around $10 \%$ in 2018, which for simplicity can be added to the adobe housing class (A), as discussed in Sect. 3.1. In short, our best estimates of the building proportions in rural conditions are $70 \%, 15 \%$, and $15 \%$ for the PAGER-based building classes A, UFB1 and UFB4, respectively.

To be consistent with the field observation presented earlier, a considerable proportion of buildings counted as UFB4 above, lacking proper lintels and/or ring beams to provide support and restraint to the masonry, should be classified as UFB*, which is an intermediate category between UFB1 and UFB4. Due to the lack of availability of reliable estimates of both the percentage and the structural fragility of this potential sub-class, this is not considered in this study but it could be addressed in future work. 
The results from the 2017 building survey indicate that an updated estimation of the current local housing stock differs from those of the global building stock model (Sect. 3.2). It is obvious that there is a significant discrepancy in the current PAGER building assignment for Malawi, with $51 \%$ of the buildings assumed to be assigned to the UCB typology), which does not agree with the current housing stock in Malawi. Compared to the results of a field survey performed in 2002 in Machinga and Phalombe, rural areas in the Southern Region of Malawi (Ngoma 2005), there is an estimated 10\% reduction of adobe block structures and a corresponding increase of fired brick structures in both urban and rural areas, which is consistent with a rapidly changing environment. It is important to keep in mind that our estimates of building classes are partial and can be improved with a more complete set of building data. The upcoming 2018 National Census will provide an excellent opportunity to update the existing building information and database for Malawi.

\section{Effects of building classifications on seismic risk assessment}

This section aims to demonstrate the importance of using realistic building data for seismic risk assessment. For this purpose, an earthquake scenario of the $M_{\mathrm{w}} 6.3$ Salima earthquake that occurred in 1989 (Gupta and Malomo 1995) is considered, and two building classification approaches are considered, i.e. the PAGER-based global building classification and the 2017-survey-based local building classification. Only brief descriptions of the seismic risk analysis method are provided in this paper; more detailed information can be found in Goda et al. (2016, 2018).

\subsection{Fragility functions for the building types identified in Malawi}

Before presenting seismic risk assessment results for the Salima earthquake case, it is important to examine the differences in the seismic vulnerability models based on the global and local building classifications. Table 2 lists the PAGER model parameters of Eq. (1) for seven building classes that are relevant to Malawian structures (Sects. 3.2 and 5.3). To show these seismic fragility functions visually, Fig. 8a compares the seismic fragility functions for these building types, whereas the approximate lognormal fragility functions defined using Eqs. (2) and (3) for the identified seven building classes are indicated with broken lines in Fig. 8b; see Table 2 for the obtained model parameters. It can be observed that M2, A, and UFB1 are more vulnerable than other building typologies (note that UFB1-mud mortar is almost as vulnerable as A, as opposed to UFB4 - cement mortar), whereas UCB exhibits significantly lower seismic vulnerability than the others. It is noted that the PAGER building classification for Malawi assumes that about a half of the building stock is of UCB type, while this does not agree with what was observed in field during the building survey (Sect. 5). Therefore, using the global building classification results in gross underestimation of seismic risk for the case of Malawi.

\subsection{Seismic risk assessment results for the Salima earthquake case}

The earthquake magnitude of the 1989 Salima earthquake was estimated as $M_{\mathrm{w}} 6.3$ and it occurred about $10 \mathrm{~km}$ north of the town of Salima. Figure 9a shows the geometries of the 
Table 2 Summary of the global and local building classifications and seismic fragility models used for the Salima earthquake case study

\begin{tabular}{llllll}
\hline \begin{tabular}{l} 
PAGER build- $\begin{array}{l}\text { ing class } \\
\text { ing }\end{array}$ \\
\cline { 2 - 5 }
\end{tabular} & Proportions of buildings & \multicolumn{3}{c}{$\begin{array}{l}{[a, b, c] \text { for } P_{\mathrm{c}}=a \times 10^{b /}} \\
(\mathrm{MMI}-\mathrm{c})\end{array}[\mathrm{Eq} .(1)]$} & $\begin{array}{l}{[\mu, \sigma] \text { for }} \\
P_{\mathrm{c}}=\Phi(\log (\mathrm{PGA} / \\
\mu) / \sigma)[\mathrm{Eq} .(3)]\end{array}$ \\
\hline M2 & 0.15 & 0.0 & 0.0 & {$[2.56,-1.69,5.18]$} & {$[0.33,0.6]$} \\
$\mathrm{A}$ & 0.19 & 0.1 & 0.7 & {$[10.76,-5.34,4.05]$} & {$[0.45,0.6]$} \\
UCB & 0.51 & 0.0 & 0.0 & {$[2.15,-5.18,5.11]$} & {$[3.50,1.1]$} \\
UFB & 0.14 & 0.0 & 0.0 & {$[3.88,-4.22,4.97]$} & {$[1.30,1.0]$} \\
UFB1 & 0.0 & 0.3 & 0.15 & {$[15.69,-7.62,3.35]$} & {$[0.58,0.7]$} \\
UFB4 & 0.0 & 0.6 & 0.15 & {$[12.63,-5.82,5.64]$} & {$[1.37,0.7]$} \\
RS & 0.01 & 0.0 & 0.0 & {$[6.17,-4.58,5.03]$} & {$[0.95,0.8]$} \\
\hline
\end{tabular}
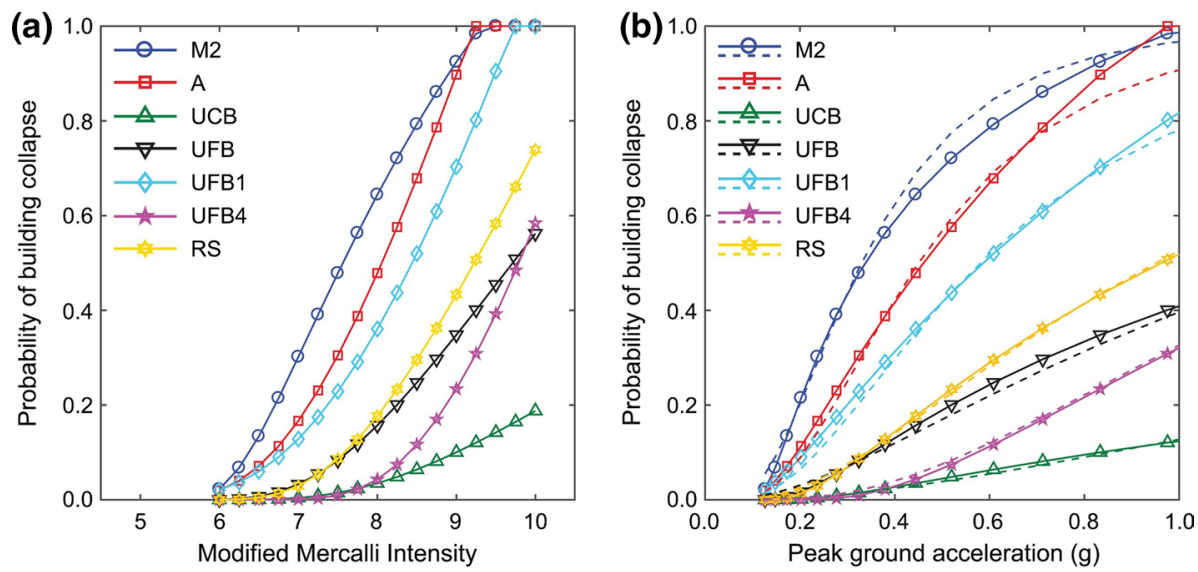

Fig. 8 Comparison of six empirical seismic fragility functions for M2, A, UCB, UFB, UFB1, UFB4, and RS by Jaiswal et al. (2011) in terms of MMI (a) and PGA (b). In (b), solid curves with symbols correspond to the converted seismic fragility functions, while the broken lines correspond to the approximated lognormal fragility functions

generated fault models. For the exposure component of the seismic risk assessment, the 2018 census population data are considered. The nationwide ratio of the populations in 2018 and 1989 is $17,563,749 / 9,094,671=1.93$. Therefore, the earthquake impact for the 1989 earthquake can be inferred by halving the results for the year 2018 as a crude estimate. Figure $9 \mathrm{~b}$ shows the spatial distribution of households in the region. The cells for the household data are based on $0.02^{\circ}$ by $0.02^{\circ}$ grids (approximately $2 \mathrm{~km}$ by $2 \mathrm{~km}$ ). For the local survey-based building classification, cells are categorised as 'urban cells' when the population density of the cell exceeds 4000 people/cell.

Figure 10 shows a realisation of seismic risk assessment for the $M_{\mathrm{w}} 6.3$ Salima scenario. In the figure, four maps are included; Fig. 10a is a PGA shake map, Fig. 10b is an affected population map by counting the number of people who experience PGA of $0.2 \mathrm{~g}$ or more, Fig. $10 \mathrm{c}$ is a building collapse map based on the global building classification, and Fig. 10d is a building collapse map based on the local building classification. For both building classification cases, the PGA shake map and affected population 

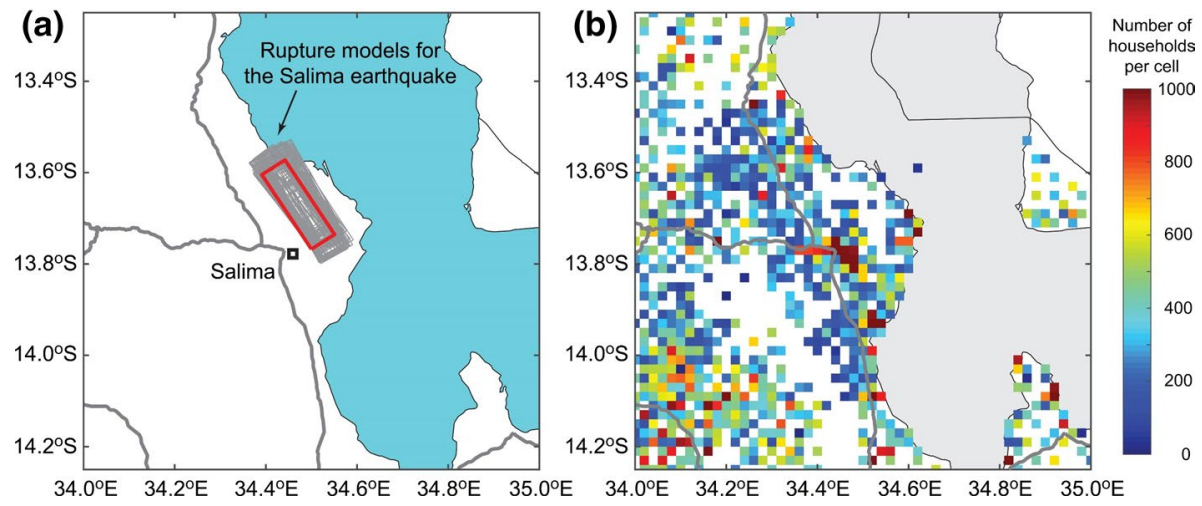

Fig. 9 a Map of the Salima region with probabilistic rupture scenarios of the 1989 Salima earthquake, and $\mathbf{b}$ household distribution in the Salima region. The cell grids are colour-coded based on the number of households in the given grids
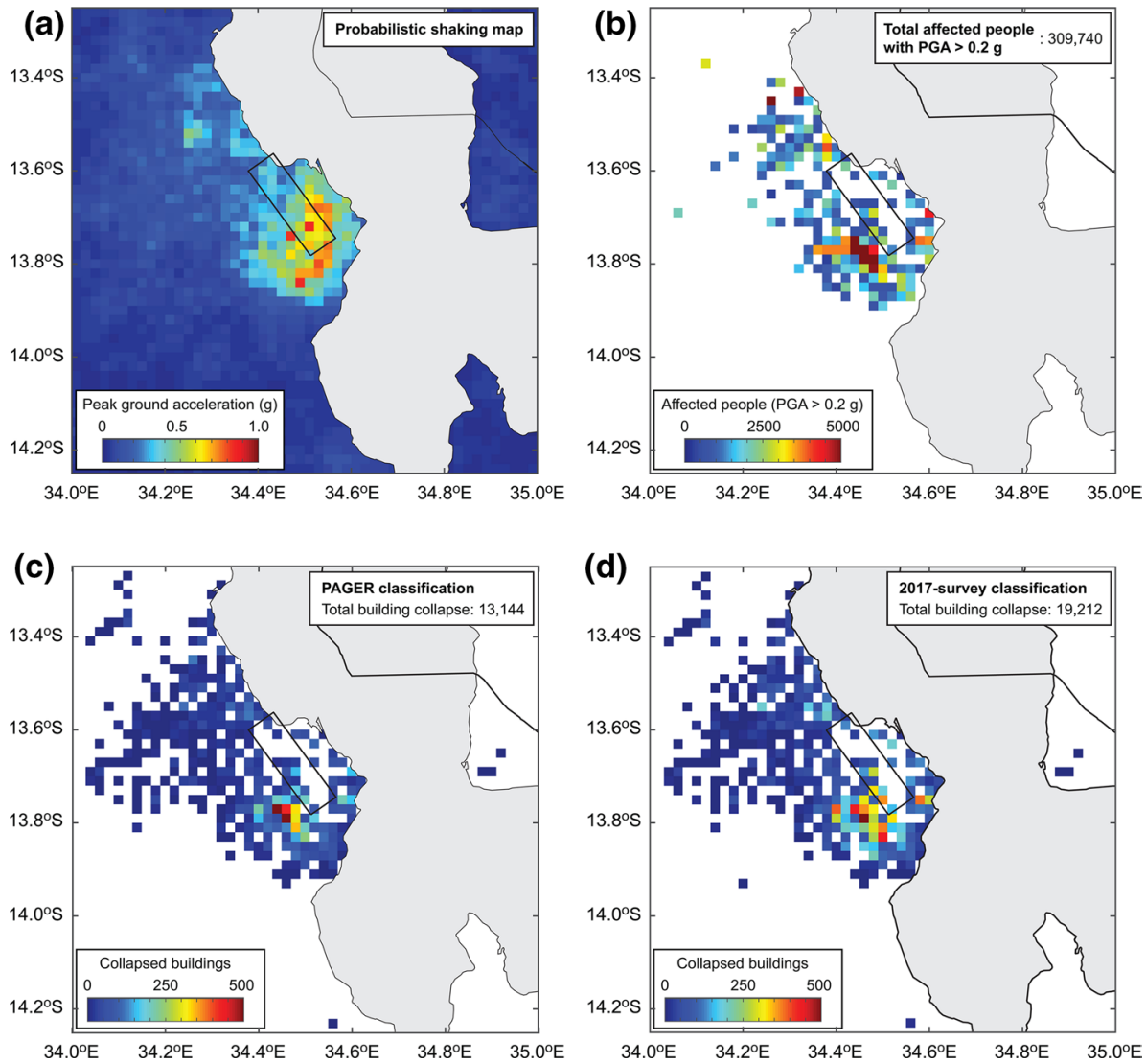

Fig. 10 Earthquake impact simulation based on a probabilistic rupture scenario: a PGA shake map, b affected population map for PGA>0.2 $\mathrm{g}$, $\mathbf{c}$ building collapse map based on the global building classification, and $\mathbf{d}$ building collapse map based on the local building classification 
Fig. 11 Comparison of the numbers of collapsed buildings based on the global and local building classifications. The results are based on 1000 rupture scenarios of the Salima earthquake

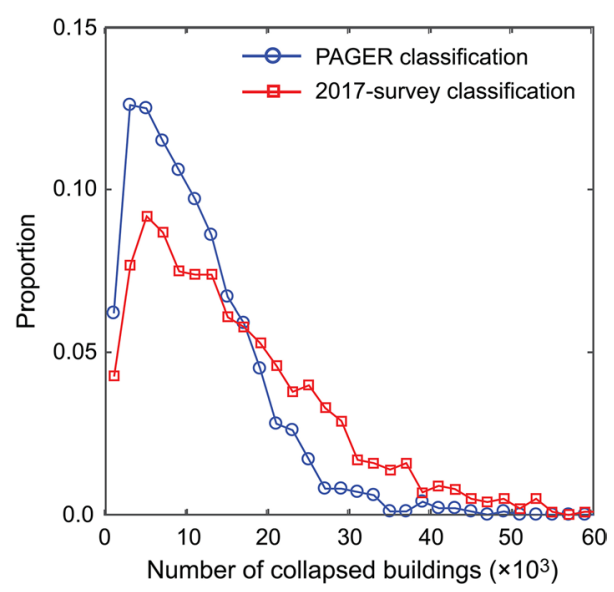

map are identical. The differences of the two building collapse maps originate from the differences of the building classifications of the current building stock and their corresponding seismic fragility functions (Table 2 and Fig. 8). The use of the local building classification leads to higher estimates of building collapse risk than the global classification case, as expected. Therefore, incorporating local building data is of importance to assess the earthquake impact accurately.

Further to confirm the effects of the building classification scheme, plots of the number of collapsed buildings based on the 1000 earthquake rupture scenarios are shown in Fig. 11. Results are presented for the two building classifications, i.e. the PAGERbased global scheme and the 2017-survey-based local scheme. Each line (with a different marker) is generated by repeating an earthquake impact assessment, like the one shown in Fig. 10, 1000 times and presents the proportions of earthquake scenarios that cause numbers of collapsed buildings in each range of 2000 buildings. The results clearly show a shift of the simulated numbers of building collapses from the global classification case to the local classification case. It is also interesting to view the simulation results from retrospective perspectives of the 1989 Salima earthquake. The US Geological Survey historical earthquake database indicates that about 50,000 people were left homeless. Assuming an average household size of 4.4 people (typical value from the 2008 and 2018 censuses), approximately, the number of severely damaged houses in the actual earthquake can be estimated as circa 10,000. By adjusting this number of damaged houses for the year 2018, a repeat of the Salima earthquake could result in 20,000 building damage. Although the seismic vulnerability of buildings in the year 1989 was different from that in the year 2018, the regional extent of the observed earthquake damage and the simulated earthquake damage using the local building classification are found to be consistent and of the same order.

\section{Conclusions}

Malawi is susceptible to multiple natural hazards with severe effects on people and the built environment. Housing conditions in local communities are critical to achieving disaster risk reduction and sustainable development. This study presents the results of 
a building survey conducted in Central and Southern Malawi by focusing upon informal housing construction with respect to seismic vulnerability. A bespoke building classification scheme, based on the PAGER system, was developed for Malawi, using the building survey results and demographic information available from the 2008 Malawi census. One of the important outcomes of this study was to derive current, realistic estimates of building class proportions for typical housing construction in Malawi. To demonstrate the influence of using realistic building data for seismic risk assessment, a case-study seismic risk assessment, focused on the $M_{\mathrm{w}} 6.3$ Salima earthquake, was discussed by considering two building classification approaches, i.e. PAGER (global) versus 2017-survey (local) building stock information. The results clearly demonstrate that seismic risk can be significantly underestimated when inaccurate global building stock information is adopted for the assessment.

Developing reliable building exposure models is an important step to obtain more accurate seismic risk profiles and thus is valuable for making more informed seismic risk management decisions. The building database forms a basis to create a road map to transform vulnerable transitional housing into more resilient permanent housing in multi-hazard environments. Moreover, to reflect the changes in demographic profiles (e.g. newly available census data), the building inventory database should be updated from time to time through field surveys. This is particularly important for countries like Malawi where rapid urbanisation is in progress.

To further advance our knowledge of seismic risk in Malawi, empirical seismic vulnerability models, which are largely based on foreign earthquake damage data, need to be improved by carrying out experimental investigations of building material properties (e.g. bricks and mortar) as well as structural elements/systems of Malawian structures. The experimental results should feed into developing realistic numerical models of structures (e.g. finite-element models). Through structural analysis of the numerical models, seismic vulnerability models of bespoke housing construction in Malawi could be developed. Eventually, they should be integrated into a comprehensive seismic risk assessment tool, capturing the improved exposure and vulnerability components.

Acknowledgements The authors wish to thank the many house owners and occupants in the surveyed areas for their willingness to allow us to survey their buildings. This work is supported by the Engineering and Physical Sciences Research Council through the PREPARE Project (EP/P028233/1).

Data availability statement This publication is in compliance with EPSRC Open Access framework. All underlying data are available to download from Kloukinas et al. (2019).

Open Access This article is distributed under the terms of the Creative Commons Attribution 4.0 International License (http://creativecommons.org/licenses/by/4.0/), which permits unrestricted use, distribution, and reproduction in any medium, provided you give appropriate credit to the original author(s) and the source, provide a link to the Creative Commons license, and indicate if changes were made.

\section{References}

Abrahamczyk, L., Schwarz, J., Langhammer, T., Genes, M. C., Bikçe, M., Kaçin, S., et al. (2013). Seismic risk assessment and mitigation in the Antakya-Maras region (SERAMAR): empirical studies on the basis of EMS-98. Earthquake Spectra, 29, 683-704.

Arya, A., Boen, T., \& Ishiyama, Y. (2014). Guidelines for Earthquake resistant non-engineered construction. Paris: International Association of Earthquake Engineering (IAEE), UNESCO. ISBN 978-92-3-000032-5. 
Boore, D. M., Stewart, J. P., Seyhan, E., \& Atkinson, G. M. (2014). NGA-West 2 equations for predicting PGA, PGV, and 5\%-damped PSA for shallow crustal earthquakes. Earthquake Spectra, 30, 1057-1085.

Brzev, S., Scawthorn, C., Charleson, A. W., Allen, L., Greene, M., Jaiswal, K., \& V. Silva, V. (2013). GEM building taxonomy (Version 2.0), Global Earthquake Model Foundation, p. 163.

Bureau TNM (2016). Safer House Construction Guidelines. Retrieved from https://issuu.com/saferconst ructionguidelines/docs/no-crocini. Accessed 1 Mar 2017.

Calvi, G. M., Pinho, R., Magenes, G., Bommer, J. J., Restrepo-Vélez, L. F., \& Crowley, H. (2006). Development of seismic vulnerability assessment methodologies over the past 30 years. ISET Journal of Earthquake Technology, 43, 75-104.

Chapola, L., \& Gondwe, J. (2016). Urban development in earthquake prone areas: Lessons from 1989 Salima and 2009 Karonga earthquakes. Journal of Catholic University Malawi, 2, 15-26.

Chaulagain, H., Rodrigues, H., Spacone, E., \& Varum, H. (2015). Seismic response of current RC buildings in Kathmandu Valley. Structural Engineering and Mechanics, 53, 791-818.

D’Ayala, D., Meslem, A., Vamvatsikos, D., Porter, K., Rossetto, T., Crowley, H., and Silva, V. (2014). Guidelines for analytical vulnerability assessment of low/mid-rise buildings: methodology. Vulnerability Global Component Project.

Flannery, J. W., \& Rosendahl, B. R. (1990). The seismic stratigraphy of Lake Malawi, Africa: Implications for interpreting geological processes in lacustrine rifts. Journal of African Earth Sciences, 10, $519-548$.

Goda, K. (2017). Probabilistic characterization of seismic deformation due to tectonic fault movements. Soil Dynamics and Earthquake Engineering, 100, 316-329.

Goda, K., Gibson, E. D., Smith, H. R., Biggs, J., \& Hodge, M. (2016). Seismic risk assessment of urban and rural settlements around Lake Malawi. Frontiers in Built Environment, 2, 30. https://doi.org/10.3389/ fbuil.2016.00030.

Goda, K., Kloukinas, P., De Risi, R., Hodge, M., Kafodya, I., Ngoma, I., Biggs, J., Crewe, A., Fagereng, A., and Macdonald, J. (2018). Scenario-based seismic risk assessment for Malawi using improved information on earthquake sources and local building characteristics. In Proceedings of the 16th European Conference on Earthquake Engineering (16ECEE), Thessaloniki, Greece, Paper 395.

Government of Malawi (2015a). Malawi 2015 floods post disaster needs assessment report. Retrieved from https://reliefweb.int/sites/reliefweb.int/files/resources/Malawi-2015-Floods-Post-Disaster-Needs-Asses sment-Report.pdf. Accessed 1 Mar 2017.

Government of Malawi (2015b). National disaster risk management policy. Retrieved from http://www.ifrc. org/docs/IDRL/43755_malawidrmpolicy2015.pdf. Accessed 1 Mar 2017.

Grünthal, G. (Ed.). (1998). European macroseismic scale 1998 (EMS-98) (p. 99). Luxembourg: Centre Européen de Géodynamique et de Séismologie.

Gupta, H. K., \& Malomo, S. (1995). The Malawi earthquake of March 10, 1989: report of field survey. Seismological Research Letters, 66, 20-27.

Hodge, M., Biggs, J., Goda, K., \& Aspinall, W. P. (2015). Assessing infrequent large earthquakes using geomorphology and geodesy in the Malawi Rift. Natural Hazards, 76, 1781-1806.

Human Development Index (2018). Human development indicators and indices: 2018 statistical update team, United Nations Development Programme-(UNDP), New York, USA. Retrieved from http://hdr. undp.org/en/2018-update. Accessed 15 Mar 2019.

Hyogo framework for action 2005-2015 (2007). Building the resilience of nations and communities to disasters. Geneva: United Nations Office for Disaster Risk Reduction. Retrieved from https://www.unisd r.org/we/coordinate/hfa. Accessed 1 Mar 2017.

International Federation of Red Cross (2011). PASSA-Participatory approach for safe shelter awareness. Retrieved from https:/www.scribd.com/document/61429462/Participatory-Approach-for-Safe-ShelterAwareness-PASSA-Manual. Accessed 1 Mar 2017.

Jackson, J., \& Blenkinsop, T. (1997). The Bilila-Mtakataka fault in Malawi: An active, 100-km long, normal fault segment in thick seismogenic crust. Tectonics, 16, 137-150.

Jaiswal, K.S., \& Wald, D.J. (2008). Creating a global building inventory for earthquake loss assessment and risk management (Open-File Report 2008-1160). US Geological Survey, p. 103.

Jaiswal, K. S., Wald, D. J., \& D'Ayala, D. (2011). Developing empirical collapse fragility functions for global building types. Earthquake Spectra, 27, 775-795.

Kloukinas, P., Novelli, V., Kafodya, I., Ngoma, I., Macdonald, J., \& Goda, K. (2019). Supporting data for 'A building classification scheme of housing stock in Malawi for earthquake risk assessment'. University of Bristol data repository. https://doi.org/10.5523/bris.14pm5de0nx8nw29az8rawx84ha.

Lang, D. H., Kumar, A., Sulaymanov, S., \& Meslem, A. (2018). Building typology classification and earthquake vulnerability scale of Central and South Asian building stock. Journal of Building Engineering, 15, 261-277. 
Lang, D.H., Singh, Y., \& Namgyel, K. (2013). Building classification scheme for Bhutan, EQRisk project report (no. 13-006), Kjeller-Roorkee-Thimphu, p. 17.

Malawi Bureau of Standards Board (2014). The structural use of masonry-Code of practice, Part 1: Unreinforced masonry walling, MS791-1.

National Statistical Office of Malawi (2008). 2008 Population and housing census. Retrieved from http:// www.nsomalawi.mw/index.php?option=com_content\&view=article\&id=106\&Itemid=6. Accessed 1 Mar 2017.

National Statistical Office of Malawi (2018). Preliminary report of 2018 population and housing census. Retrieved from https://malawi.unfpa.org/sites/default/files/resource-pdf/2018\%20Census\%20Prelimin ary\%20Report.pdf. Accessed 15 Mar 2019.

Ngoma, I. (2005). State-of-art and sustainable improvements of traditional Sub-Saharan African housing with special reference to Malawi. Ph.D. Thesis, University of Pisa, Italy.

Novelli, V., Kloukinas, P., Ngoma, I., Kafodya, I., Macdonald, J., \& Goda, K. (2018). Unreinforced masonry houses made of fired clay bricks (Report 205), World Housing Encyclopedia. Retrieved from http:// db.world-housing.net/building/205/. Accessed 15 Mar 2019.

Poggi, V., Durrheim, R., Tuluka, G. M., Weatherill, G., Gee, R., Pagani, M., et al. (2017). Assessing seismic hazard of the East African Rift: A pilot study from GEM and AfricaArray. Bulletin of Earthquake Engineering, 15, 4499-4529.

Sassu, M., \& Ngoma, I. (2002). Rural mud wall building (Reports 43), Rammed earth house with pitched roof (Report 45), and Unburnt brick wall building with pitched roof (Report 46), World Housing Encyclopedia. Retrieved from http://db.world-housing.net/43,45and46/. Accessed 1 Mar 2017.

Sendai framework for disaster risk reduction 2015-2030 (2015). In: UN world conference on disaster risk reduction, 2015 March 14-18, Sendai, Japan. Geneva: United Nations Office for Disaster Risk Reduction; 2015. Retrieved from https://www.unisdr.org/we/coordinate/sendai-framework. Accessed 1 Mar 2017.

Siddique, M. S., \& Schwarz, J. (2015). Elaboration of multi-hazard zoning and qualitative risk maps of Pakistan. Earthquake Spectra, 31, 1371-1395.

So, E., \& Spence, R. (2013). Estimating shaking-induced casualties and building damage for global earthquake events: A proposed modelling approach. Bulletin of Earthquake Engineering, 11, 347-363.

UN-Habitat (2010). Malawi: Urban housing sector profile. Retrieved from https://unhabitat.org/books/ malawi-urban-housing-sector-profile/. Accessed 1 Mar 2017.

Wald, D. J., \& Allen, T. I. (2007). Topographic slope as a proxy for seismic site conditions and amplification. Bulletin of the Seismological Society of America, 97, 1379-1395.

Wald, D. J., Quitoriano, V., Heaton, T. H., \& Kanamori, H. (1999). Relationships between peak ground acceleration, peak ground velocity, and modified Mercalli intensity in California. Earthquake Spectra, 15, 557-564.

World Housing Encyclopedia (2019). World housing database, joint project by the Earthquake Engineering Research Institute-EERI and the International Association of Earthquake Engineering-IAEE. Retrieved from http://www.world-housing.net/. Accessed 15 Mar 2019.

Publisher's Note Springer Nature remains neutral with regard to jurisdictional claims in published maps and institutional affiliations.

\title{
Affiliations
}

\section{Panos Kloukinas ${ }^{1}$ (D) Viviana Novelli ${ }^{2} \cdot$ Innocent Kafodya ${ }^{3} \cdot$ Ignasio Ngoma $^{3}$. John Macdonald ${ }^{2} \cdot$ Katsuichiro Goda ${ }^{4}$}

\author{
Viviana Novelli \\ vn18530@bristol.ac.uk \\ Innocent Kafodya \\ ikafodya@poly.ac.mw \\ Ignasio Ngoma \\ ingoma@poly.ac.mw
}


John Macdonald

john.macdonald@bristol.ac.uk

Katsuichiro Goda

kgoda2@uwo.ca

1 Faculty of Engineering and Science, University of Greenwich, Medway Campus, P351 Pembroke Building, Chatham Maritime ME4 4TB, UK

2 Department of Civil Engineering, University of Bristol, Bristol, UK

3 Department of Civil Engineering, University of Malawi, The Polytechnic, Blantyre, Malawi

4 Department of Earth Sciences, Western University, London N6A 5B7, Canada 